Article

\title{
Is Urban Economic Output Decoupling from Water Use in Developing Countries?-Empirical Analysis of Beijing and Shanghai, China
}

\author{
Xiaowei Wang ${ }^{1}$ and Rongrong $\mathrm{Li}^{1,2, *}$ \\ 1 School of Economics and Management, China University of Petroleum (East China), Qingdao 266580, China \\ 2 School of Management \& Economics, Beijing Institute of Technology, Haidian District, Beijing 100081, China \\ * Correspondence: lirr@upc.edu.cn
}

Received: 23 May 2019; Accepted: 26 June 2019; Published: 28 June 2019

check for updates

\begin{abstract}
Water issue is one of the challenges of urban sustainability in developing countries. To address the conflict between urban water use and economic development, it is required to better understand the decoupling states between them and the driving forces behind these decoupling states. The transformed Tapio decoupling model is applied in this paper to study the decoupling relationship between urban industrial water consumption and economic growth in Beijing and Shanghai, two megacities in China, in 2003-2016. The factors driving decoupling are divided into industrial structure effect, industrial water utilization intensity effect, economic development level effect, and population size effect through Logarithmic Mean Divisia Index (LMDI) method. The results show that: (1) the decoupling states of total water consumption and economic growth in Beijing and Shanghai are mainly strong decoupling and weak decoupling. In comparison, Shanghai's decoupling effect is better than Beijing; (2) regarding decoupling elasticity, Beijing is higher than that of Shanghai in tertiary industry and lower in primary industry and secondary industry. As a result, Beijing's decoupling level is worse than Shanghai in tertiary industry, while better in primary industry and secondary industry; (3) The common factors that drive the two megacities' decoupling are industrial structure effect and industrial water utilization intensity effect. The effects of economic development level and population size mainly present weak decoupling in two megacities, but the decoupling state is optimized year by year. Finally, based on the results, some suggestions for achieving the sustainable development of urban water use are proposed.
\end{abstract}

Keywords: LMDI; urban water use; economic growth; decoupling

\section{Introduction}

Human life and production and social economic development are closely connected with water resources, whose development can be hardly achieved without water resources support. Nowadays, developing countries are vigorously promoting the development of urban economy to keep pace with the developed countries. Water is an important factor in supporting economic growth [1]. Developing countries have a large population, accounting for more than $70 \%$ of the world's population. As a result, the per capita resource of developing countries is relatively low, implying a serious shortage of water resources. As the world's largest developing country, China maintains rapid economic structure growth and has become the world's second largest economy. In addition, China's economy has transformed dramatically [2]. However, China's per capita water resources are only $2300 \mathrm{~m}^{3}$-about one quarter of the world's per capita water resources. The conflict between water supply and demand is increasingly intensified [3]. As one of the 13 water-deficient countries in the world, China can maintain its leading economic development, reflecting that the growth rate of urban water use is lower than the speed of 
economic development, and there is a decoupling relationship between urban water use and economic development. Therefore, studying the decoupling of urban water use and economic growth in China and the factors driving decoupling are of great significance for creating a water-saving society and promoting the sustainable use of urban water resources.

Beijing and Shanghai are the two leading cities in China. Whether from the perspective of total GDP, people's quality of life, urbanization, or the city's international influence, the two cities are ahead of most cities in China [4]. The remaining cities in China target these two megacities, exerting great efforts to develop and improve themselves in all aspects. It can be said that the current development of Beijing and Shanghai represents the future of other similar cities. Therefore, we choose Beijing and Shanghai as the research object. With the rapid development of economy and society in Beijing, the capital of China, the resource-based water shortage features of "many people and less water" have gradually become prominent. The per capita water resources in Beijing is about $300 \mathrm{~m}^{3}$ [5], which is about $1 / 8$ of the national average and $1 / 30$ of the world average. There is no doubt that water shortage is a serious and urgent problem by far. The future demand for water will show a rigid growth, which will intensify the conflict between water supply and demand. As a first-tier city in China, Shanghai has experienced rapid economic development in recent years. Similar to the shortage of water in Beijing, the per capita water resource in Shanghai was only $163.1 \mathrm{~m}^{3}$, accounting for just $7 \%$ of the national average [6]. Beijing and Shanghai, as China's economic centers, play a leading role in economic development. In order to solve the problem of water shortage and promote the decoupling of economic growth from water use, the two megacities implemented some relevant measures. For example, Beijing has formulated the most stringent water resources management system and created 60 kinds of penalties for non-conservation of water [7]. Shanghai has implemented the "Several Provisions on Water Resources Management in Shanghai" since January 1, 2018 [8]. Under the implementation of relevant policies, the two megacities continue to make progress in saving water and improving water use efficiency while maintaining rapid economic development.

Furthermore, the Central Committee of the Communist Party of China and the State Council issued some relevant documents stating that Beijing and Tianjin will be the center to lead the development of the Beijing-Tianjin-Hebei urban agglomeration [9], and Shanghai as the center to lead the development of the Yangtze River Delta urban agglomeration [10]. Obviously, Beijing and Shanghai are able to play a demonstrative role in economic development. Therefore, analyzing the decoupling levels of economic growth and water use in Beijing and Shanghai, studying the common factors of promoting the decoupling of economic development from water use in two megacities, and comparing the respective advantages of each city are of great significance, which is beneficial for the sustainable development of urban water use in two megacities. In addition, it can provide theoretical references to other cities and promote sustainable development of China's water use.

The remainder of this paper is organized as follows: Section 2 presents a literature review. In Section 3, we introduce the research methods and data sources. Tapio decoupling model and LMDI decomposition method are involved. In Section 4, we analyze the decoupling state between water use and economic growth in Beijing and Shanghai. Further, there are four decoupling driving factors be decomposed. Conclusions and recommendations are listed in Section 5.

\section{Literature Review}

\subsection{Overview of the Decoupling Theory}

The relationship between economic growth and resource consumption is often complex. There is a decoupling relationship between them when the rate of resource consumption is lower than economic growth. The decoupling model involves different academic fields and is currently widely used in the field of resource and environment. Many analysis methods have been proposed to measure the decoupling level. At the beginning of the 21st century, the Organization for Economic Co-operation and Development (OECD) made a report on the "Measurement of the Decoupling 
Relationship between Economic Growth and Environmental Impacts". For the first time, the concept of decoupling was defined from the perspective of economics, that is, the link between economic growth and environmental impact has had attention paid to it [11]. Decoupling was divided into absolute decoupling and relative decoupling, applied to the field of agricultural policy, and then gradually expanded to the field of resources and environment. Juknys [12] further refined the decoupling, saying that primary decoupling is the decoupling between economic growth and natural resource consumption, secondary decoupling is the decoupling between natural resource consumption and environmental pollution, and double decoupling is the case when primary decoupling and secondary decoupling occur simultaneously. Vehmas [13] found that there is not only a phenomenon of decoupling in the process of economic development, the opposite phenomenon also occurs frequently. So, he proposed to combine the decoupling and the coupling to understand the definition of decoupling and divided the six decoupling states. Tapio [14] perfected the decoupling model. He studied the decoupling relationship between the traffic volume, GDP and carbon dioxide emissions of 15 countries in the European Union in 1970-2001, and proposed eight decoupling states. Zhong et al. [15] divided the decoupling into four types: two-point method, three-point method, six-point method, and eight-point method. He argued that different decoupling concepts in different research purposes and research fields have their own advantages and disadvantages.

Based on the above-mentioned decoupling theories, scholars from various countries have started a series of studies on decoupling from the provincial and municipal levels to the national level and even the global level.

\subsubsection{Research at the National or Provincial Level}

Song [16] studied the decoupling relationship between Beijing's economic growth and the loss of cultivated land occupied by the construction industry. Gokarakonda et al. [17] analyzed the mechanism of the Indian construction industry and proposed related measures to achieve decoupling between resource consumption, environmental impact, and economic growth. Fan et al. [18] and Wang et al. [19] decoupled the $\mathrm{CO}_{2}$ emissions and economic growth in Beijing and Shanghai, respectively. Jiang et al. [20] combined environmental Kuznets curve with decoupling to study the decoupling of economic growth and carbon dioxide emissions in Guangdong Province in 1995-2014, and found that the decoupling state is mainly weak decoupling, and strong decoupling may be achieved in the long run. Chen et al. [21] studied the decoupling between greenhouse gas emissions and economic growth. Zhang et al. [22] measured the capacity utilization rate of the coal industry and its decoupling from the economic growth of China's supply-side reform. Cui et al. [23] explored the decoupling between regional economic growth and the extent to which pollution affects the region. Yuan et al. [24] used decoupling and spatial correlation analysis to study the temporal and spatial interactions between four ecosystem services and urbanization in Nanjing. Shi et al. [25] and Wang et al. [26] revealed the decoupling levels between energy consumption and economic development in various provinces of China. Dasgupta et al. [27] analyzed the Indian energy intensity trends from 1973 to 2012 and concluded that the decline in energy intensity could offset a major portion of the growing energy demand, leading to a decoupling trend. Lesin et al. [28] utilized Russian water use to determine the decoupling effect of raw material.

\subsubsection{Research at the Global or Multiple National Level}

Mikayilov et al. [29] applied the time-varying cointegration approach to study the decoupling relationship between GDP and carbon dioxide in 12 countries in Western Europe in 1861-2015. Moreau et al. [30] analyzed the nature of the EU's 1990-2014 decoupling between energy consumption and carbon emissions and economic growth, and identified three influencing factors. Moutinho et al. [31] conducted a two-step analysis of the decoupling of carbon dioxide and GDP in 16 Latin American countries through DEA analysis to assess ecological efficiency. MADS [32] believed that the decoupling of water from energy consumption should be a global priority. Csereklyei et al. [33] proposed the 
factors driving global energy use growth are economic growth, energy intensity, and weak decoupling. Tu et al. [34] conducted an empirical study of the Group of Seven (G7) and BRICS countries to analyze energy decoupling rates and decarbonization trends to improve energy efficiency and mitigate global warming and climate change. Schandl et al. [35] used a new approach to economic and environmental models to assess the decoupling potential of 13 world regions and global regions.

\subsection{Overview of Decoupling Analyses Based on Decomposition Methods}

At present, more and more people combine decoupling and other methods to further explore the deeper level of decoupling, as shown in Table 1.

Table 1. Summary of main literature using decoupling combined with other methods.

\begin{tabular}{|c|c|c|c|c|}
\hline Literature & Target & Scope & Period & Methods \\
\hline Li et al. [36] & $\begin{array}{l}\text { carbon emissions } \rightarrow \\
\text { economic growth }\end{array}$ & $\begin{array}{l}\text { construction land in } \\
\text { Shanghai, China }\end{array}$ & 1999-2015 & Kaya, LMDI \\
\hline Xie et al. [37] & $\begin{array}{l}\mathrm{CO}_{2} \text { emission } \rightarrow \\
\text { economic growth }\end{array}$ & power industry in China & 1985-2016 & Tapio, LMDI \\
\hline Wang et al. [38] & $\begin{array}{l}\mathrm{CO}_{2} \text { emissions } \rightarrow \\
\text { economic output }\end{array}$ & $\begin{array}{l}\text { manufacturing industry in } \\
\text { China }\end{array}$ & 1996-2010 & Kaya, LMDI \\
\hline Lin et al. [39] & $\begin{array}{l}\mathrm{CO}_{2} \text { emissions } \rightarrow \\
\text { economic output }\end{array}$ & heavy industry in China & 1991-2015 & Kaya, LMDI \\
\hline He et al. [40] & $\begin{array}{c}\text { carbon emissions } \rightarrow \\
\text { economic growth } \\
\text { carbon emissions } \rightarrow\end{array}$ & $\begin{array}{l}\text { fossil energy consumption } \\
\text { in China }\end{array}$ & 1995-2013 & Tapio, LMDI \\
\hline Zhao et al. [41] & $\begin{array}{c}\text { water \& land resource } \\
\text { exploitation }\end{array}$ & agriculture in China & 2005-2013 & Decoupling, LMDI \\
\hline Wang et al. [42] & $\begin{array}{l}\text { carbon emission } \rightarrow \\
\text { electric output }\end{array}$ & $\begin{array}{l}\text { electricity sector in } \\
\text { Shandong, China }\end{array}$ & 1995-2012 & Tapio, LMDI \\
\hline Dong et al. [43] & $\begin{array}{l}\text { carbon emissions } \rightarrow \\
\text { economic growth }\end{array}$ & $\begin{array}{c}\text { energy use in Northwest } \\
\text { China }\end{array}$ & 1995-2012 & Decoupling, LMDI \\
\hline Zhao et al. [44] & $\begin{array}{l}\mathrm{CO}_{2} \text { emission } \rightarrow \\
\text { economic growth }\end{array}$ & $\begin{array}{l}\text { five major economic } \\
\text { sectors }\end{array}$ & 1992-2012 & Decoupling, LMDI \\
\hline Jiang et al. [45] & $\begin{array}{l}\text { carbon emissions } \rightarrow \\
\text { economic growth }\end{array}$ & $\begin{array}{l}\text { energy-related use in } \\
\text { the United States }\end{array}$ & 1990-2014 & Decoupling, LMDI \\
\hline Zhang et al. [46] & $\begin{array}{l}\text { energy consumption } \rightarrow \\
\text { economic growth }\end{array}$ & $\begin{array}{l}\text { Liaoning Province in } \\
\text { China }\end{array}$ & 1995-2012 & Decoupling, LMDI \\
\hline Wang et al. [47] & $\begin{array}{l}\text { carbon emissions } \rightarrow \\
\text { economic growth }\end{array}$ & six sectors in China & 2000-2014 & $\begin{array}{l}\text { Cobb-Douglas } \\
\text { production function, } \\
\text { LMDI }\end{array}$ \\
\hline Wang et al. [48] & $\begin{array}{l}\text { fuel consumption } \rightarrow \\
\text { economic growth }\end{array}$ & China and India & 1990-2015 & $\begin{array}{c}\text { Cobb-Douglas } \\
\text { production function, } \\
\text { LMDI }\end{array}$ \\
\hline Zhou et al. [49] & $\begin{array}{l}\text { carbon emissions } \rightarrow \\
\text { economic growth }\end{array}$ & energy use in China & 1996-2012 & Big data, Tapio, LMDI \\
\hline Wang et al. [50] & $\begin{array}{l}\text { carbon emissions } \rightarrow \\
\text { economic growth }\end{array}$ & transport sector in China & 2000-2016 & Decoupling, LMDI \\
\hline Wang et al. [51] & $\begin{array}{l}\text { carbon emissions } \rightarrow \\
\text { economic output }\end{array}$ & $\begin{array}{c}\text { industrial sectors in Beijing } \\
\text { and Shanghai, China }\end{array}$ & 2000-2015 & Decoupling, LMDI \\
\hline Roinioti et al. [52] & $\begin{array}{c}\mathrm{CO}_{2} \text { emission } \rightarrow \\
\text { economic growth } \\
\text { greenhouse gas }\end{array}$ & energy use in Greece & 2003-2013 & $\begin{array}{l}\text { Decoupling, } \\
\text { decomposition }\end{array}$ \\
\hline Leal et al. [53] & $\begin{array}{l}\text { emissions } \rightarrow \\
\text { economic growth }\end{array}$ & all sectors in Australia & 1990-2015 & Decoupling, LMDI \\
\hline Song et al. [54] & $\begin{array}{l}\text { energy consumption } \rightarrow \\
\text { economic growth }\end{array}$ & all sectors in China. & 1991-2012 & ZM Decoupling, LMDI \\
\hline Ning et al. [55] & $\begin{array}{c}\mathrm{CO}_{2} \text { emission } \rightarrow \\
\text { economic development }\end{array}$ & energy-related in China & 1996-2013 & WCDM, Tapio \\
\hline Wang et al. [56] & $\begin{array}{l}\text { carbon emissions } \rightarrow \\
\text { economic growth }\end{array}$ & China and India & 1980-2014 & $\begin{array}{l}\text { Decoupling, } \\
\text { decomposition }\end{array}$ \\
\hline Wang et al. [57] & $\begin{array}{l}\text { carbon emissions } \rightarrow \\
\text { economic growth }\end{array}$ & $\begin{array}{l}\text { China and } \\
\text { the United States }\end{array}$ & 2000-2014 & Decoupling, LMDI \\
\hline
\end{tabular}

Note: A $\rightarrow$ B represents the action that decoupling A from B. LMDI represents Logarithmic Mean Divisia Index method. Kaya represents Kaya identity. ZM represents a new decoupling indicator (ZM Decoupling Indicator). WCDM represents Weighting Complete Decomposition Model. 
We found that the combination of decoupling and factor decomposition methods to further systematically study the factors driving decoupling has gradually attracted the attention of scholars. The decomposition method was originally widely used in the economic field to quantify the factors behind variable changes. Due to the global oil crisis in the 1970s, people paid attention to the deeper reason of energy consumption changes, and decomposition method was introduced into the field of energy consumption. There are two main decomposition methods, Structural Decomposition Analysis (SDA) and Index Decomposition Analysis (IDA) [58], as shown in Figure 1. SDA uses information from the input and output tables, while IDA uses summary data at the sector level. Comparing the two methods, the IDA method has two advantages. First of all, the IDA method mainly studies objects with fewer driving factors and is more widely used. Second, the SDA method requires a complete study of regional input and output data. The generation of these data is phased, and the data collected is often not up to date. The IDA method is based on time series data, and the data is up-to-date and representative. At present, there are two kinds of factor decomposition methods that are more applied, one is the Logarithmic Mean Divisia Index (LMDI) method proposed by Ang [59], and the other is the Laspeyres decomposition method modified by Sun [60]. The LMDI method has a fixed base period and has several advantages, such as decomposing without residual, addition decomposition and multiplication decomposition consistency. It is currently the most widely used and most effective decomposition method [61].

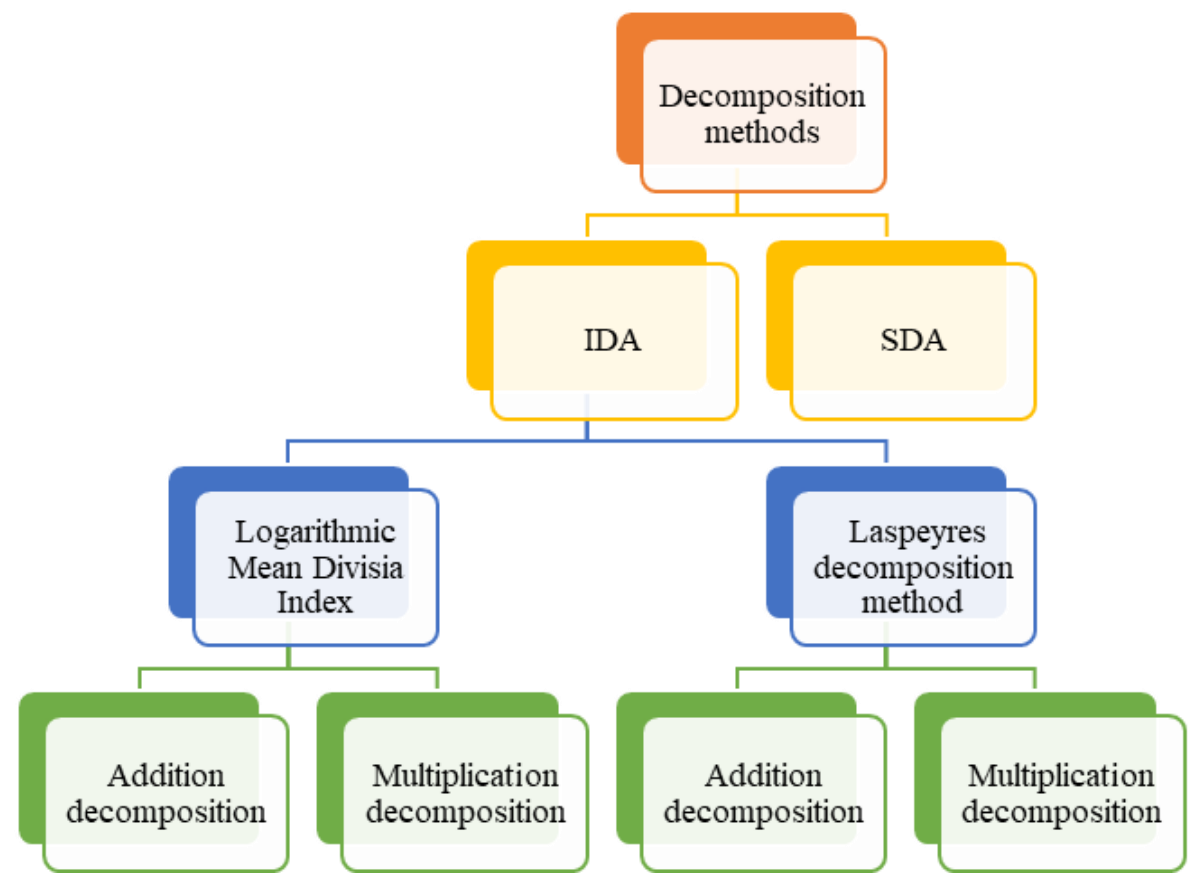

Figure 1. Factor decomposition methods.

\subsection{Research on Water Decoupling}

Through Sections 2.1 and 2.2, we found that the current researches mainly focus on the relationship between economic growth and energy consumption and environmental pollution, and most of them involve the relationship between carbon emissions and economic growth. There are relatively few researches on water decoupling, only the following studies exist, as shown in Figure 2. Hu et al. [62] and Wang et al. [63] studied the decoupling relationship and driving factors between water consumption and economic growth in Jiangxi and Tianjin, respectively, based on the LMDI and Tapio decoupling models. Qiu et al. [64] used the improved Tapio decoupling model and the STochastic Impacts by Regression (STIRPAT) model to explore the driving factors of groundwater consumption in the Yellow Sea and the coastal area of the Bohai Sea. Li et al. [65] analyzed the decoupling relationship between water consumption and economic growth in China's textile industry, and used the Laspeyres 
decomposition method to decompose the decoupling factors, and proposed a strategic approach to achieve strong decoupling. Zhang et al. [66] explored the decoupling and driving force of water consumption and China's thermoelectric power generation growth by compiling a time series of water consumption in the thermoelectric power sector. Li et al. [67] analyzed the driving force of water consumption in China's energy production process based on the LMDI method. Zhang et al. [68] quantitatively analyzed the contribution of driving factors to agricultural water use in different stages of the Heihe River.

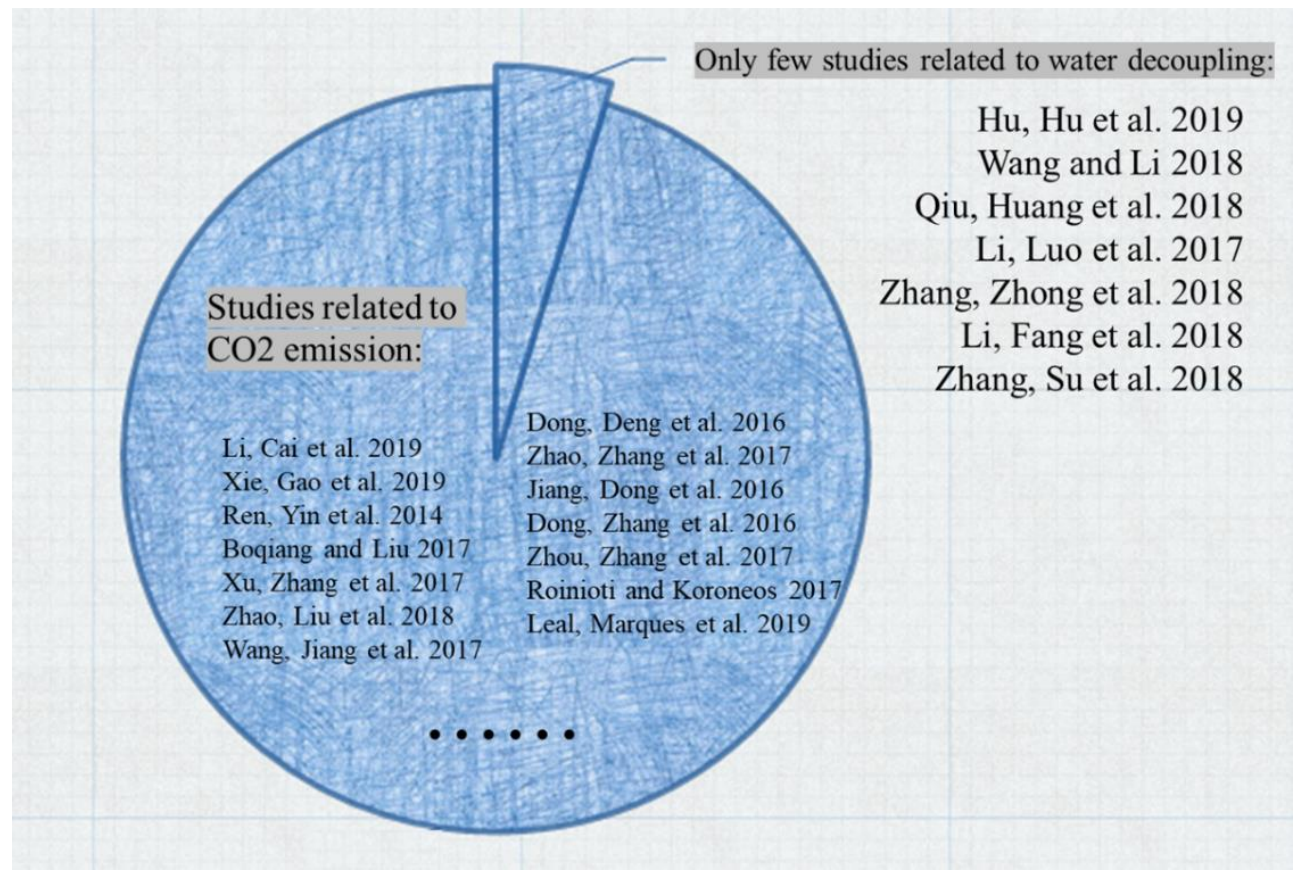

Figure 2. Studies involving carbon emissions decoupling analyses and water decoupling analyses.

Two research levels, decoupling state and combined decomposition method, have been reviewed above. Through the literature review, we found that: (i) Regarding the research area, the current research on the decoupling relationship between water use and economic growth is still insufficient. It is only preliminary, and the depth and breadth of research are far less than other fields such as carbon emissions and energy consumption. However, water resources are critical to sustainable development. Our life and economic development are inseparable from the support of water resources. Therefore, the systematic decoupling of water consumption from economic growth is urgently needed. (ii) Regarding the research method, the comprehensive analysis of decoupling combined with LMDI has been widely applied. Through the above-mentioned literature, the results of this analytical method are reliable. Therefore, it is believable for us to study the decoupling between water consumption and economic growth by using decoupling and LMDI methods. (iii) Regarding the research objects' characteristics, most of the current literature research objects are individual province or country, and it is rare to have a comparative study in two cities. However, a comparative study can find commonalities and differences between the two cities. Furthermore, it is of great significance to explore the factors that drive common characteristics and the reasons for the differences.

According to the findings, it remains scarce that research on comparing the decoupling of water consumption and economic growth in two cities and exploring the factors affecting decoupling. In order to cover the research gaps mentioned above, this paper's aim's to study the decoupling relationship between urban water use and economic growth by Tapio decoupling theory, and further apply LMDI method to decompose the driving factors, and then focus on a comparative study of two megacities-Beijing and Shanghai. There are two contributions we make: (i) This paper systematically studies the decoupling state of industrial water use and economic growth in Beijing and Shanghai, 
and further decomposes the decoupling driving factors. We used a comprehensive analytical method, decoupling combined with LMDI, to have systematic research. First, we analyzed the decoupling level of total industrial water use and economic growth in the two megacities, and the decoupling state of the three sub-sectors. Through it, we can make up the gap that the scarce research on water decoupling. And then, we combined the LMDI method to decompose the Kaya identity to get the four driving factors that affect decoupling. Further, we found the factors that promote decoupling from them. Therefore, policy recommendations for regulating these factors for environmental sustainability can be proposed. (ii) This study is a comparative analysis in two megacities. Through analysis, we found that the decoupling levels of the two megacities are both optimistic. Further, we explored the common characteristics that drive the two megacities' decoupling. It is not only of great importance to improve the development of the two megacities, but also provide theoretical basis and reference for other cities' sustainable development. By comparison, we found that Shanghai's decoupling effect is better than Beijing. The reason for the difference is that Shanghai's industrial water intensity factor more effectively promotes decoupling, and the factors that inhibit decoupling are less effective. Through finding the difference in the development advantages of each city and comparing the respective characteristics of each city, we can propose more targeted recommendations to promote water decoupling.

\section{Methodology and Data}

\subsection{Water Decoupling Model}

As we all know, [14] proposed the concept of decoupling elasticity. The Tapio model is mainly used to measure the decoupling relationship between carbon emissions and economic growth. The model is defined as:

$$
\mathrm{t}=\frac{\Delta \mathrm{CO}_{2} / \mathrm{CO}_{2}}{\Delta \mathrm{GDP} / \mathrm{GDP}}
$$

In order to study the decoupling relationship between urban water use and economic growth, this paper makes a variable transformation based on expression (1) to construct a water decoupling model, which is defined as follows: In the $0-\mathrm{t}$ period, the decoupling elasticity index of urban water use $(\mathrm{H})$ and economic growth $(\mathrm{G})$ is defined as:

$$
\mathrm{D}=\frac{\Delta \mathrm{H} / \mathrm{H}}{\Delta \mathrm{G} / \mathrm{G}}
$$

In this expression: $\mathrm{D}$ denotes the decoupling elasticity index of urban water use and economic growth; $\Delta \mathrm{H} / \mathrm{H}$ represents the urban industrial water consumption growth rate; $\Delta \mathrm{G} / \mathrm{G}$ represents the economic growth rate.

Tapio divided the decoupling into eight states. For the purpose of not overinterpret changes as significant, and combined with the data analysis of this paper, there are six decoupling levels be divided ( $\pm 20 \%$ change in elasticity values around 1.0 is not considered). The measurement standards for the decoupling degree are shown in Table 2.

Table 2. Six decoupling states.

\begin{tabular}{ccccc}
\hline & $\boldsymbol{\Delta H}$ & $\boldsymbol{\Delta} \boldsymbol{G}$ & $\mathrm{D}$ & Decoupling Degree \\
\hline \multirow{3}{*}{ Decoupling } & $<0$ & $>0$ & $\mathrm{D} \leq 0$ & Strong decoupling (SD) \\
& $>0$ & $>0$ & $0<\mathrm{D} \leq 1$ & Weak decoupling (WD) \\
& $<0$ & $<0$ & $\mathrm{D}>1$ & Recessive decoupling (RD) \\
\hline \multirow{2}{*}{ Negative } & $>0$ & $<0$ & $\mathrm{D} \leq 0$ & Strong negative decoupling (SND) \\
decoupling & $<0$ & $<0$ & $0<\mathrm{D} \leq 1$ & Weak negative decoupling (WND) \\
& $>0$ & $>0$ & $\mathrm{D}>1$ & Expansive negative decoupling (END) \\
\hline
\end{tabular}


The decoupling state occurs when the water consumption growth rate is lower than the economic growth rate. Further, there are three levels are subdivided: strong decoupling, weak decoupling, and recessive decoupling. The most ideal phenomenon is that while economic growth is accompanied by a continuous decline in water consumption, the dependence of economic growth on water consumption is waning, that is, the state of strong decoupling. The undesired state is negative decoupling, that is, the growth rate of water consumption is higher than the speed of economic growth, and there are three states of strong negative decoupling, expansive negative decoupling and weak negative decoupling. The strong negative decoupling is the worst state, that is, the water consumption increases but the economy output declines. The framework of decoupling states is shown in Figure 3.

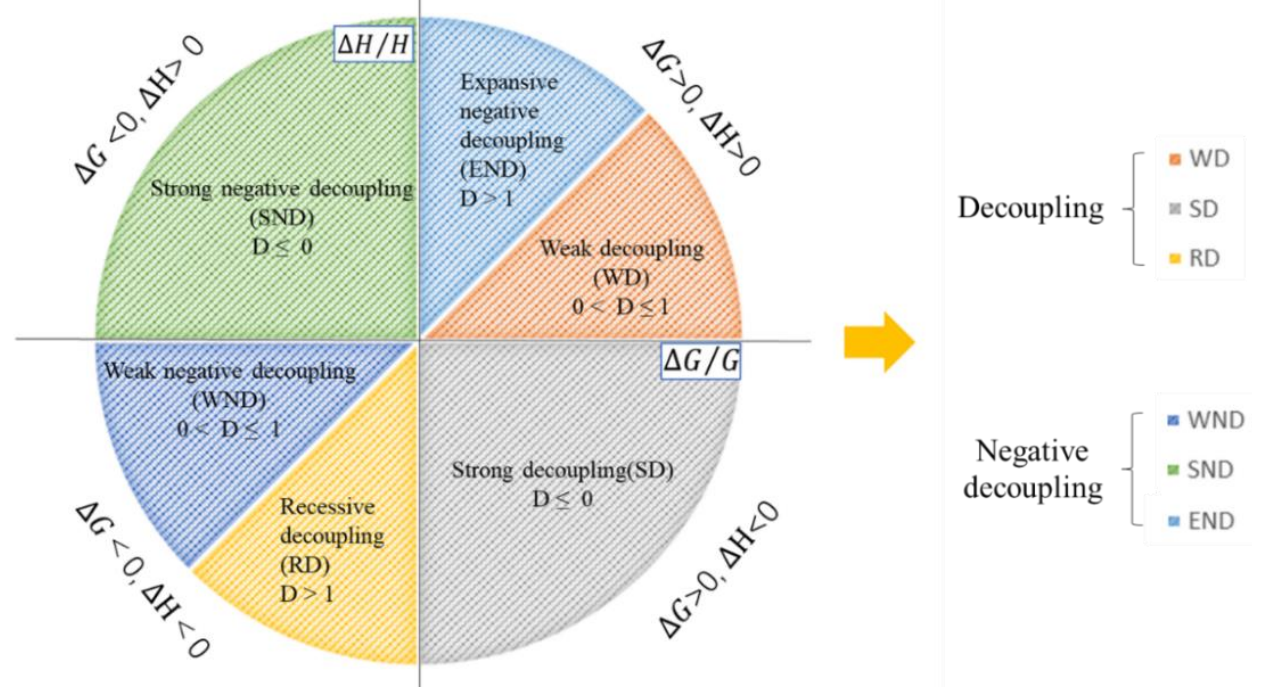

Figure 3. Framework of decoupling states.

\subsection{Water Decoupling Decomposition Model Based on LMDI}

As noted in Section 2, LMDI method has the advantages of decomposing no residual, addition decomposition and multiplication decomposition consistency. It is currently the most widely used and most effective decomposition method. Therefore, this paper uses the LMDI addition decomposition method. To decompose urban water use, Kaya identity [69] needs to be established as the first step to deploy the LMDI decomposition analysis. The formula (2) defines the decoupling index of urban water use $(\mathrm{H})$ and economic growth $(\mathrm{G})$. Considering human impact on the environment $(\mathrm{I})$, the I=PAT equation sets it equal to the product of population (P), affluence (A), and technology (T) [70]. Due to population growth, increased consumption of rich people and inadequate choice of technology and social arrangements for the supply of such consumption, global change has created a series of environmental problems. Therefore, population, affluence, technology, and social arrangements are the key factors affecting the environment. Through the I = PAT equation, we chose four representative indicators to build the Kaya identity for urban water use in China.

$$
\mathrm{H}=\sum_{\mathrm{i}=1}^{3} \mathrm{H}_{\mathrm{i}}=\sum_{\mathrm{i}=1}^{3} \frac{\mathrm{H}_{\mathrm{i}}}{\mathrm{G}_{\mathrm{i}}} \times \frac{\mathrm{G}_{\mathrm{i}}}{\mathrm{G}} \times \frac{\mathrm{G}}{\mathrm{p}} \times \mathrm{p}
$$

where $\mathrm{H}$ represents the total urban water use; Hi represents the water used in the i-th industry; $\mathrm{G}$ represents the total value of production; Gi represents the added value of the i-th industry; $p$ represents the population.

Order: hi $=\mathrm{Hi} / \mathrm{Gi}$ represents the amount of water consumed by the i-th industry unit of GDP, that is, the intensity of industrial water use; $\mathrm{di}=\mathrm{Gi} / \mathrm{G}$ represents the ratio of the added value of the i-th industry to the gross domestic product, that is, the industrial structure; $g=G / p$ represents per capita 
GDP, which is the level of economic development. And hi, di, $g$ and $p$ reflect the above-mentioned factors of technology, social arrangements, affluence and population, respectively.

Therefore, the formula (4) can be written as:

$$
\mathrm{H}=\sum_{i=1}^{3} \mathrm{hi} \times \mathrm{di} \times \mathrm{g} \times \mathrm{p}
$$

Order: $t$ and 0 are the water use in final year and initial year respectively. The LMDI addition decomposition method is used to define the decomposition formula for the change of water consumption during the $0-\mathrm{t}$ period:

$$
\Delta \mathrm{H}=\mathrm{Ht}-\mathrm{H} 0=\Delta \mathrm{Hh}+\Delta \mathrm{Hd}+\Delta \mathrm{Hg}+\Delta \mathrm{Hp}+\Delta \mathrm{Hr}
$$

where $\mathrm{Ht}$ and $\mathrm{H} 0$ represent the urban industrial water consumption in the $\mathrm{t}$ year and the initial year respectively; $\Delta \mathrm{H}$ represents the amount of water change in the $0-\mathrm{t}$ period; $\Delta \mathrm{Hh}$ is the industrial water utilization intensity effect, that is, the amount of urban industrial water change caused by industrial water utilization intensity; $\Delta \mathrm{Hd}$ is the industrial structure effect, that is, the amount of urban industrial water change caused by the industrial structure; $\Delta \mathrm{Hg}$ is the economic development level effect, that is, the amount of urban industrial water change caused by the level of economic development; $\Delta \mathrm{Hp}$ is the population effect, that is, the amount of urban industrial water change caused by the population size; $\Delta \mathrm{Hr}$ represents the decomposition residual. In formula (5):

$$
\begin{aligned}
& \Delta \mathrm{H}_{\mathrm{h}}=\sum_{\mathrm{i}} \mathrm{W}\left(\mathrm{H}_{\mathrm{i}}^{\mathrm{t}}, \mathrm{H}_{\mathrm{i}}^{0}\right) \times \ln \frac{\mathrm{h}_{\mathrm{i}}^{\mathrm{t}}}{\mathrm{h}_{\mathrm{i}}^{0}} \\
& \Delta \mathrm{H}_{\mathrm{d}}=\sum_{\mathrm{i}} \mathrm{W}\left(\mathrm{H}_{\mathrm{i}}^{\mathrm{t}}, \mathrm{H}_{\mathrm{i}}^{0}\right) \times \ln \frac{\mathrm{d}_{\mathrm{i}}^{\mathrm{t}}}{\mathrm{d}_{\mathrm{i}}^{0}} \\
& \Delta \mathrm{H}_{\mathrm{g}}=\sum_{\mathrm{i}} \mathrm{W}\left(\mathrm{H}_{\mathrm{i}}^{\mathrm{t}}, \mathrm{H}_{\mathrm{i}}^{0}\right) \times \ln \frac{\mathrm{g}^{\mathrm{t}}}{\mathrm{g}^{0}} \\
& \Delta \mathrm{H}_{\mathrm{p}}=\sum_{\mathrm{i}} \mathrm{W}\left(\mathrm{H}_{\mathrm{i}}^{\mathrm{t}}, \mathrm{H}_{\mathrm{i}}^{0}\right) \times \ln \frac{\mathrm{p}^{\mathrm{t}}}{\mathrm{p}^{0}}
\end{aligned}
$$

In the formula (6)-(9), $W\left(\mathrm{H}_{\mathrm{i}}^{t}, \mathrm{H}_{\mathrm{i}}^{0}\right)$ is a weight function, which is defined as follows:

$$
W\left(\mathrm{H}_{\mathrm{i}}^{t}, \mathrm{H}_{\mathrm{i}}^{0}\right)=\left\{\begin{array}{cc}
\frac{\mathrm{H}_{\mathrm{i}}^{t}-\mathrm{H}_{\mathrm{i}}^{0}}{\ln \mathrm{H}_{\mathrm{i}}^{t}-\ln \mathrm{H}_{\mathrm{i}}^{0}} & \left(\mathrm{H}_{\mathrm{i}}^{t} \cdot \mathrm{H}_{\mathrm{i}}^{0} \neq 0\right) \\
\mathrm{H}_{\mathrm{i}}^{t} & \left(H_{\mathrm{i}}^{t}=\mathrm{H}_{\mathrm{i}}^{0}\right) \\
0 & \left(\mathrm{H}_{\mathrm{i}}^{t} \cdot \mathrm{H}_{\mathrm{i}}^{0}=0\right)
\end{array}\right.
$$

Calculate the decomposition residual as follows:

$$
\begin{aligned}
\Delta \mathrm{Hr} & =\Delta \mathrm{H}-(\Delta \mathrm{Hh}+\Delta \mathrm{Hd}+\Delta \mathrm{Hg}+\Delta \mathrm{Hp}) \\
& =\mathrm{Ht}-\mathrm{H} 0-\sum_{\mathrm{i}} \mathrm{W}\left(\mathrm{H}_{\mathrm{i}^{\mathrm{t}}}^{\mathrm{t}} \mathrm{H}_{\mathrm{i}}^{0}\right) \times\left(\ln \frac{\mathrm{h}_{\mathrm{i}}^{\mathrm{t}}}{\mathrm{h}_{\mathrm{i}}^{0}}+\ln \frac{\mathrm{d}_{\mathrm{i}}^{\mathrm{t}}}{\mathrm{d}_{\mathrm{i}}^{0}}+\ln \frac{\mathrm{g}^{\mathrm{t}}}{\mathrm{g}^{0}}+\ln \frac{\mathrm{p}^{\mathrm{t}}}{\mathrm{p}^{0}}\right) \\
& =\mathrm{Ht}-\mathrm{H} 0-\sum_{\mathrm{i}} \mathrm{W}\left(\mathrm{H}_{\mathrm{i}}^{\mathrm{t}}, \mathrm{H}_{\mathrm{i}}^{0}\right) \times \ln \frac{\mathrm{H}_{\mathrm{t}}}{\mathrm{H}_{0}} \\
& =0
\end{aligned}
$$

Therefore, the LMDI method has the advantage of decomposing no residual. According to the water decoupling model and the LMDI decomposition method and the simultaneous Equations (2) and (5), the water decoupling decomposition model is constructed: 


$$
\mathrm{D}=\frac{\Delta \mathrm{H} / \mathrm{H}}{\Delta \mathrm{G} / \mathrm{G}}=\frac{\Delta \mathrm{H}_{\mathrm{h}} / \mathrm{H}}{\Delta \mathrm{G} / \mathrm{G}}+\frac{\Delta \mathrm{H}_{\mathrm{d}} / \mathrm{H}}{\Delta \mathrm{G} / \mathrm{G}}+\frac{\Delta \mathrm{H}_{\mathrm{g}} / \mathrm{H}}{\Delta \mathrm{G} / \mathrm{G}}+\frac{\Delta \mathrm{H}_{\mathrm{p}} / \mathrm{H}}{\Delta \mathrm{G} / \mathrm{G}}=\mathrm{Dh}+\mathrm{Dd}+\mathrm{Dg}+\mathrm{Dp}
$$

where D represents the decoupling elastic index of urban water use and economic growth; Dh represents the decoupling elastic index of industrial water utilization intensity; Dd represents the decoupling elastic index of the industrial structure; Dg represents the decoupling elasticity index of economic development level; Dp represents the decoupling elasticity index of population size.

\subsection{Data Sources}

This paper mainly studies the decoupling between water consumption and economic growth in Beijing and Shanghai. We collect the data about the total water consumption, the three industrial water consumption, the gross domestic product, the added value of the three industries, and the total population in Beijing and Shanghai in 2003-2016. In order to eliminate the impact of price changes, the added value of the three industries was converted into the constant price in 2003. The above data mainly come from the China Statistical Yearbook [71], the Beijing Statistical Yearbook [72], and the Shanghai Statistical Yearbook [73].

\section{Results and Discussion}

\subsection{Analysis of the Decoupling Relationship}

\subsubsection{Decoupling between Total Water Consumption and Economic Growth in Beijing and Shanghai}

The annual GDP and total water consumption in Beijing and Shanghai in 2003-2016 are shown in Figure 4a. We can see that the GDP of Beijing and Shanghai is growing at a relatively steady rate year by year. The average annual growth rate of GDP in Beijing and Shanghai in 2003-2016 was 9.78\% and $10.86 \%$, respectively. The total water use in Shanghai fluctuates greatly, and in Beijing is relatively flat. The average annual growth rate of total water use in Beijing and Shanghai in 2003-2016 was 0.60\% and $-0.29 \%$, respectively. In comparison, the total GDP and total water consumption of Shanghai are always higher than those of Beijing. Further, the growth rate of total water use in Shanghai is negative, the growth rate of Beijing's water use is positive, and Shanghai's GDP growth rate is higher than that of Beijing. It can be seen that Shanghai has effectively saved water resources while vigorously developing its economy. Compared with Beijing, Shanghai has better water-saving conditions and is more in line with sustainable development.
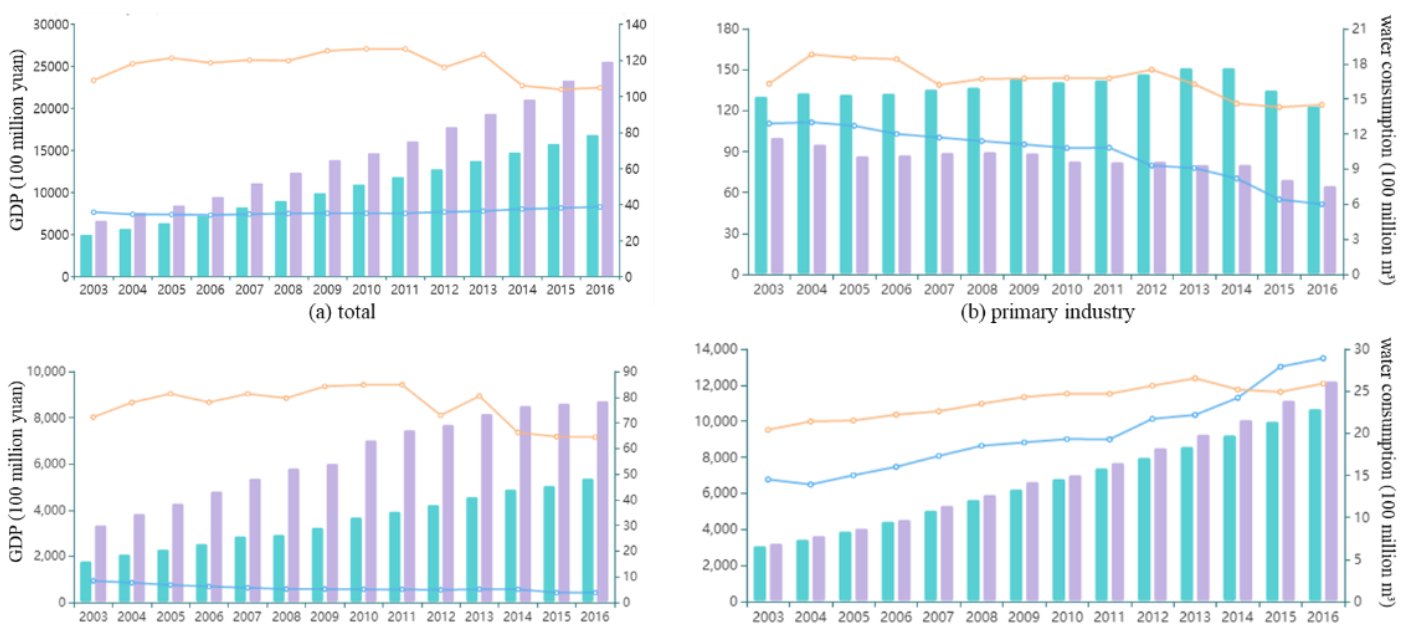

(c) secondary industry

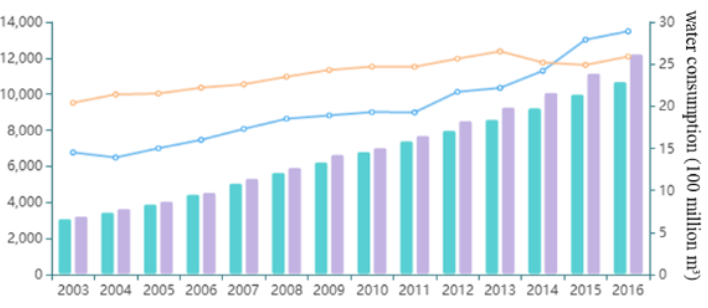

(d) tertiary industry

Beijing(GDP) Shanghai(GDP) -O- Beijing(water consumption) - Shanghai(water consumption)

Figure 4. Annual GDP and water consumption in Beijing and Shanghai in 2003-2016. 
The decoupling elastic index of total water use and economic growth in Beijing and Shanghai in 2003-2016 is shown in Figure 5. It can be seen that decoupling states in the two megacities is dominated by strong decoupling and weak decoupling. Beijing shows the change of "strong decoupling-weak decoupling-strong decoupling-weak decoupling". There is no stable decoupling trend in Shanghai. The frequency of strong decoupling in Beijing and Shanghai was $38.46 \%$ and $46.15 \%$ respectively. The decoupling effects of Beijing and Shanghai are both well. In comparison, Shanghai's strong decoupling status is more frequent than in Beijing. Combined with the analysis of the data in Figure 4a, it is clear that Shanghai's economic growth is faster than Beijing's, and the annual water consumption growth rate is negative. Moreover, Shanghai is more inclined to develop the state of strong decoupling in recent years. Therefore, Shanghai's decoupling efforts are relatively better than Beijing.

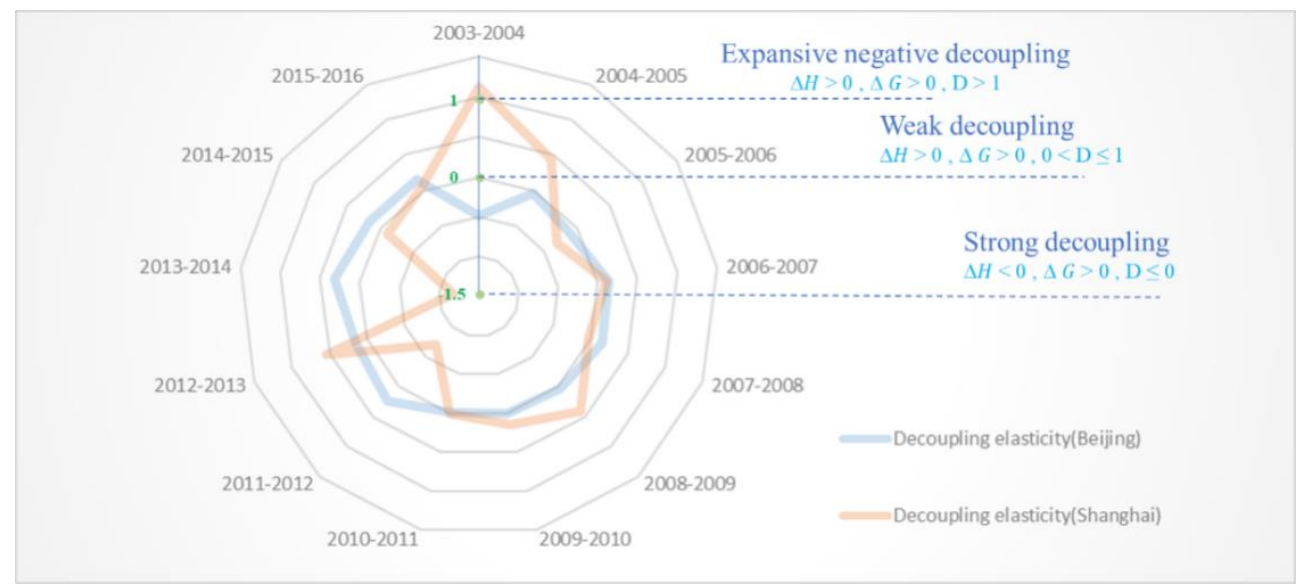

Figure 5. Decoupling elastic index of water consumption and economic growth in Beijing and Shanghai in 2003-2016.

4.1.2. Decoupling between Water Consumption and Economic Growth of Three Industries in Beijing and Shanghai

The GDP and water use of the three industries in Beijing and Shanghai in 2003-2016 are shown in Figure $4 \mathrm{~b}-\mathrm{d}$. It presents that the water use in the primary and secondary industries in Beijing and Shanghai has been declining year by year, and the Beijing' trend is more obvious than that in Shanghai. The average annual growth rates of them were $-5.72 \%,-5.92 \%$ in Beijing and $-0.90 \%,-0.88 \%$ in Shanghai respectively. The GDP of Beijing's primary industry fluctuated greatly, and the GDP of Shanghai's primary industry showed a relatively obvious downward trend. The GDP of the secondary industry of both megacities maintained an upward trend. Annual GDP growth rates of primary and secondary industries were $-0.44 \%, 8.80 \%$ in Beijing and $-3.28 \%, 7.64 \%$ in Shanghai respectively. The GDP and water use of the tertiary industry in Beijing and Shanghai are both increasing year by year, and the two variables are positively correlated.

The decoupling elastic of the three industrial water use and economic growth in Beijing and Shanghai in 2003-2016 are shown in Table 3; Table 4. Comparing Table 3; Table 4, it can be seen that there is a relatively stable decoupling state between Beijing's three industrial water use and economic growth. Shanghai's primary industry water use and economic growth have a significant negative decoupling state, while the secondary industry and tertiary industry are in a relatively stable decoupling state. To be more specific, the water use of Beijing's primary industry and secondary industry has decreased drastically, while economic growth has risen rapidly. Beijing's primary industry and secondary industry decoupling index is smaller than Shanghai. The decoupling state of the primary industry and secondary industry in Beijing is dominated by strong decoupling, especially the strong decoupling of the secondary industry, while Shanghai mainly presented negative decoupling and weak decoupling. It can be seen that Beijing is superior to Shanghai in the production of water in the primary industry and secondary industry. Beijing's tertiary industry has a higher growth 
rate than Shanghai, and its GDP growth rate is lower than that of Shanghai. Therefore, Shanghai's tertiary industry is dominated by weak decoupling and strong decoupling. In recent years, Beijing has experienced expansive negative decoupling state. In comparison, Shanghai's tertiary industry saves water better than Beijing.

Table 3. Decoupling elastic index of Beijing's three industries water consumption and economic growth.

\begin{tabular}{ccccccc}
\hline \multirow{2}{*}{ Year } & \multicolumn{7}{c}{ Beijing } \\
\cline { 2 - 7 } & $\mathbf{D}_{\mathbf{1}}$ & Decoupling State & $\mathbf{D}_{\mathbf{2}}$ & Decoupling State & $\mathbf{D}_{\mathbf{3}}$ & Decoupling State \\
\hline $2003-2004$ & 0.5369 & WD & -1.4825 & SD & -0.5579 & SD \\
$2004-2005$ & 3.7538 & RD & -2.7006 & SD & 0.8178 & WD \\
$2005-2006$ & -11.7727 & SD & -1.5730 & SD & 0.6066 & WD \\
$2006-2007$ & -1.3678 & SD & -0.9807 & SD & 0.7062 & WD \\
$2007-2008$ & -2.6768 & SD & -4.6050 & SD & 0.6756 & WD \\
$2008-2009$ & -0.6120 & SD & 0.0000 & SD & 0.2313 & WD \\
$2009-2010$ & 1.7982 & RD & -0.1427 & SD & 0.2302 & WD \\
$2010-2011$ & 0.3144 & WD & -0.1027 & SD & -0.0169 & WD \\
$2011-2012$ & -4.4694 & SD & -0.3438 & SD & 1.3855 & END \\
$2012-2013$ & -0.6306 & SD & 0.4072 & WD & 0.2582 & WD \\
$2013-2014$ & 3.8042 & SD & -0.0402 & SD & 1.0501 & END \\
$2014-2015$ & 1.4654 & RD & -5.1108 & SD & 1.6485 & END \\
$2015-2016$ & 0.4532 & WND & 0.0000 & SD & 0.4769 & WD \\
\hline
\end{tabular}

Table 4. Decoupling elastic index of Shanghai's three industries water consumption and economic growth.

\begin{tabular}{ccccccc}
\hline \multirow{2}{*}{ Year } & \multicolumn{7}{c}{ Shanghai } \\
\cline { 2 - 6 } & $\mathbf{D}_{\mathbf{1}}$ & Decoupling State & $\mathbf{D}_{\mathbf{2}}$ & Decoupling State & $\mathbf{D}_{\mathbf{3}}$ & Decoupling State \\
\hline $2003-2004$ & -2.5352 & SND & 0.9555 & WD & 0.7139 & WD \\
$2004-2005$ & 0.1799 & WND & 0.6446 & WD & 0.0735 & WD \\
$2005-2006$ & -0.7323 & SD & -0.5246 & SD & 0.4283 & WD \\
$2006-2007$ & -6.3934 & SD & 0.4982 & WD & 0.1533 & WD \\
$2007-2008$ & 4.0701 & END & -0.3228 & SD & 0.4458 & WD \\
$2008-2009$ & -0.2572 & SND & 1.8913 & WD & 0.3298 & WD \\
$2009-2010$ & -0.0433 & SND & 0.0497 & WD & 0.3146 & WD \\
$2010-2011$ & 0.3500 & WND & 0.0094 & WD & -0.0088 & SD \\
$2011-2012$ & 9.1301 & END & -4.3167 & SD & 0.3504 & WD \\
$2012-2013$ & 2.6247 & RD & 1.3399 & WD & 0.3499 & WD \\
$2013-2014$ & 12.8331 & SD & -3.4672 & SD & -0.4860 & SD \\
$2014-2015$ & 0.1393 & WND & -1.3099 & SD & -0.0809 & SD \\
$2015-2016$ & -0.2215 & SND & -0.1618 & SD & 0.2784 & WD \\
\hline
\end{tabular}

\subsection{Analysis of Decoupling Driving Factors}

In order to further explore the driving factors of decoupling, this study combines the water decoupling model and the LMDI method to decompose the urban total water use and economic growth decoupling elasticity into: industrial structure decoupling elasticity, industrial water utilization intensity decoupling elasticity, economic development level decoupling elasticity and population size decoupling elasticity. Decoupling elastic index decomposition in Beijing and Shanghai in 2003-2016 is shown in Figure 6. We can see that the common factors that drive the two megacities' decoupling are industrial structure effect and industrial water utilization intensity effect. The effects of economic development level and population size mainly present weak decoupling in two megacities.

The upgrading of the industrial structure represents the direction of China's future economic reforms. The industrial structure changes in Beijing and Shanghai from 2003 to 2016 are shown in Figure 7. The proportion of the primary industry in the two cities has dropped below $0.50 \%$ in 2016 , and the tertiary industry has reached more than $60 \%$. The General Office of the Beijing Municipal People's Government issued and continuously improved the guidance for accelerating the development of the tertiary industry. Shanghai started its pilot reform in 2012 in the transportation industry and some modern service industries. They have promoted the rapid development of the tertiary industry 
in the two megacities. The decrease in the proportion of the primary industry and secondary industry with higher water consumption and lower output, the increase in the proportion of the tertiary industry with less water consumption and higher output, makes the industrial structure is gradually optimized.

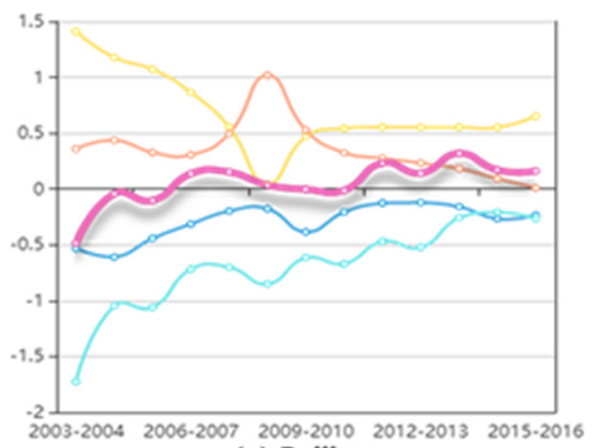

(a) Beijing

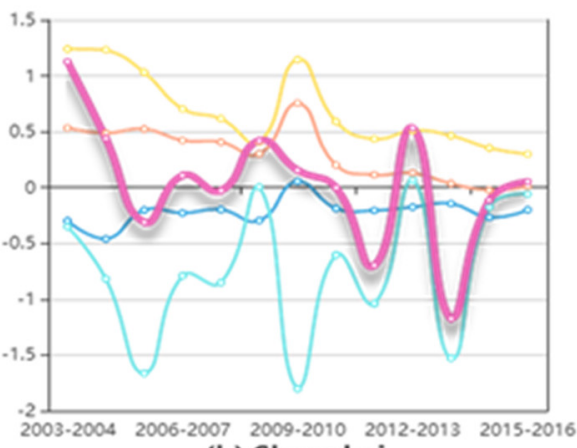

(b) Shanghai

- Decoupling elasticity of industrial structure - Decoupling elasticity of industrial water utilization intensity

Decoupling elasticity of economic development level - Decoupling elasticity of population

- Total decoupling elasticity

Figure 6. Beijing and Shanghai water use and economic growth decoupling elastic index decomposition in 2003-2016.

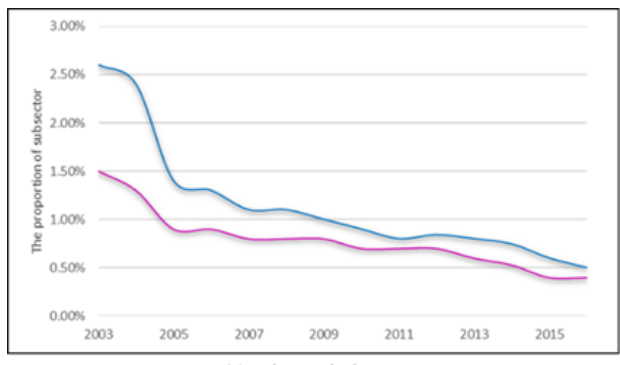

(a) primary industry

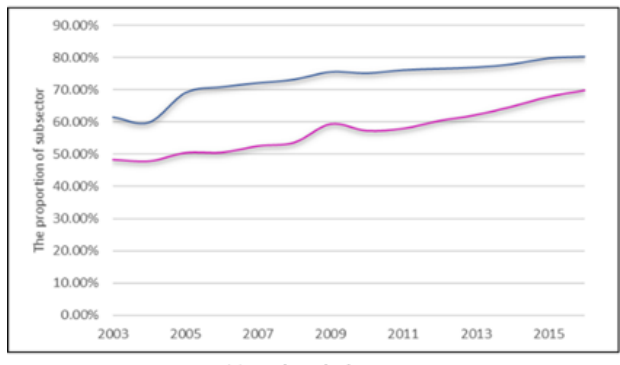

(c) tertiary industry

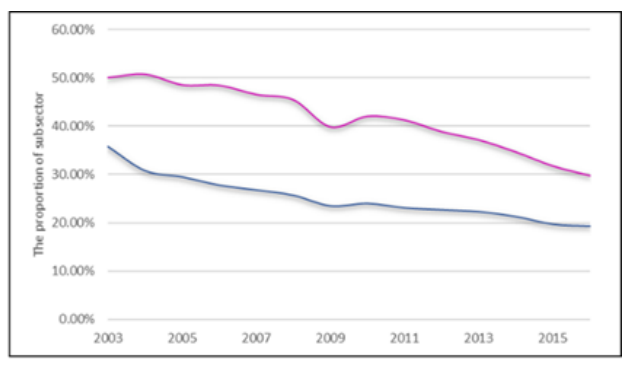

(b) secondary industry

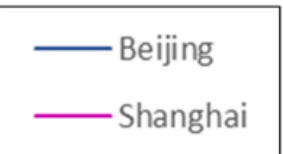

Figure 7. Changes in the three major industrial structures in Beijing and Shanghai in 2003-2016.

From Figure 6, we found that the industrial structure effect has driven the decoupling between water consumption and economic growth in Beijing and Shanghai, and the two megacities both show strong decoupling. Through comparing the two cities, we can realize that the declining rate of the primary and secondary industry's proportion in Beijing is significantly faster than that of Shanghai. The growth rate of Beijing's primary industry proportion and secondary industry proportion were $-11.91 \%$ and $-9.67 \%$ respectively, and that of Shanghai were $-9.67 \%$ and $-3.92 \%$ respectively. As shown in Figure 9a, the decoupling index of Beijing's industrial structure is lower than that of Shanghai. Therefore, the effect of Beijing's industrial structure on decoupling is better than that of Shanghai. It reflects that Beijing's industrial structure optimization is better than Shanghai.

The industrial water utilization intensity represents the technical parameters in the IPAT equation. From an analysis of decoupling index shown in Figure 6, we found the effect of industrial water utilization intensity has a driving effect on the decoupling of water use from economic growth in 
Beijing and Shanghai, and the effect is more obvious than the industrial structure effect. The changes in water utilization intensity of the three industries in Beijing and Shanghai from 2003 to 2016 are shown in Figure 8. We can see that the intensity of water use in Beijing and Shanghai has shown a significant downward trend. It shows that the water consumption per unit of GDP is decreasing. In comparison, the water utilization intensity of the primary industry in Beijing has been maintained at $0.150 \mathrm{~m}^{3} / \mathrm{yuan}$, and has dropped to $0.050 \mathrm{~m}^{3}$ /ten thousand yuan in 2016, and the secondary industry and tertiary industry have maintained at less than $0.005 \mathrm{~m}^{3} / y$ uan. The water utilization intensity of Shanghai's primary industry and secondary industry dropped to $0.129 \mathrm{~m}^{3} /$ yuan and $0.008 \mathrm{~m}^{3} /$ yuan respectively in 2016. Shanghai's annual water utilization intensity is higher than that of Beijing, and Beijing's three industries have better water use efficiency than Shanghai. However, as shown in Figure 9b, Shanghai's decoupling index is lower. Shanghai's water utilization intensity has been declining year by year faster than Beijing (Figure 9), indicating that Shanghai has been actively improving water-saving technologies and accelerating its development in the past 13 years. The water utilization intensity of the primary industry in the two megacities is still high, which inhibits the driving force of industrial water utilization intensity on decoupling. Therefore, the two cities should actively seek ways to improve the water efficiency of the primary industry. At the same time, they should not slack off the water-saving innovation technologies of the secondary and tertiary industries, taking the road of sustainable development.

The economic development level and the population size show the level of urbanization, and symbolize the two parameters of the affluence and population of the IPAT equation. As is shown in Figure 6, the effect of economic development level and population size have no obvious driving effect on the decoupling between water use and economic growth in Beijing and Shanghai. The economic development level effect of the two megacities showed expansive negative decoupling in 2003-2006. After 2006, the phenomenon of weak decoupling was basically maintained. That is to say, the economic growth is accompanied by an increase in water consumption. However, the decoupling index is decreasing year by year, indicating that the water consumption required for economic growth is declining year by year, reflecting the contribution of the two megacities to building a water-saving society and developing water-saving innovation technologies.

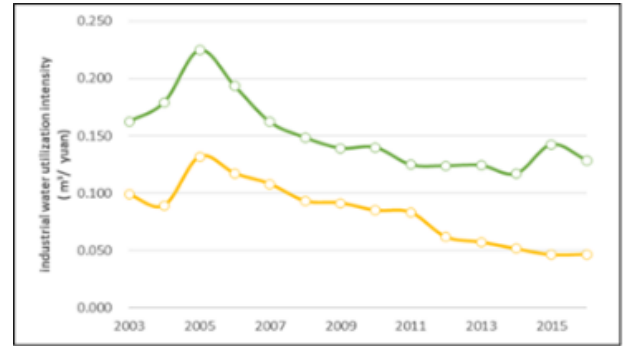

(a) primary industry

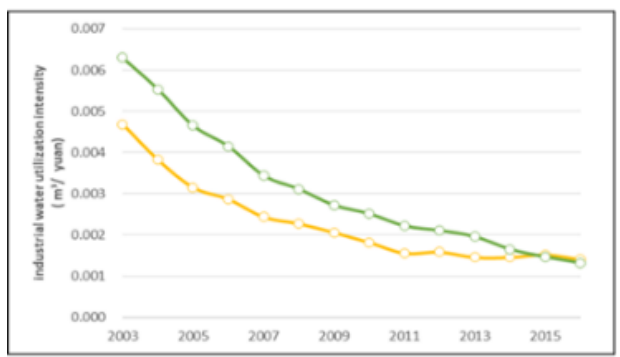

(c) tertiary industry
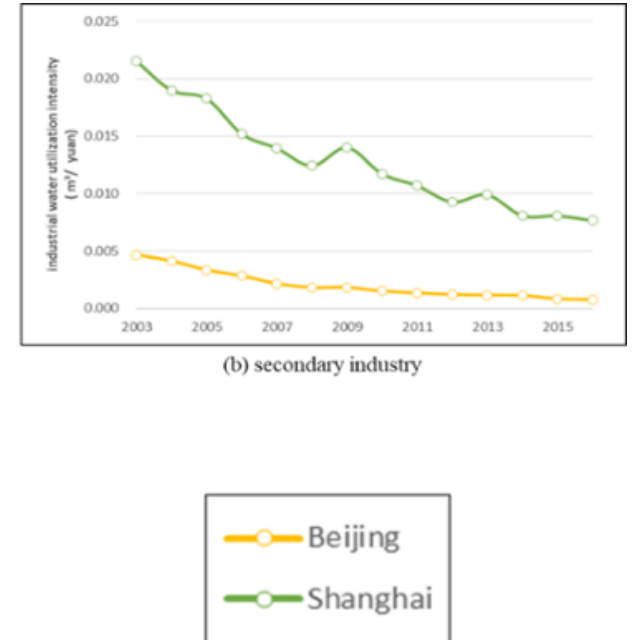

Figure 8. Changes in the intensity of water utilization in the three industries in Beijing and Shanghai in 2003-2016. 


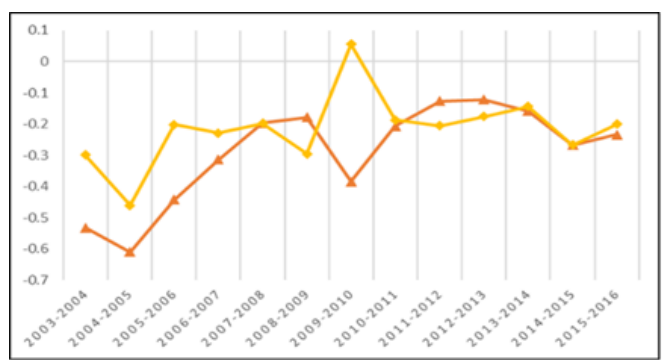

(a) $\mathrm{Dd}$

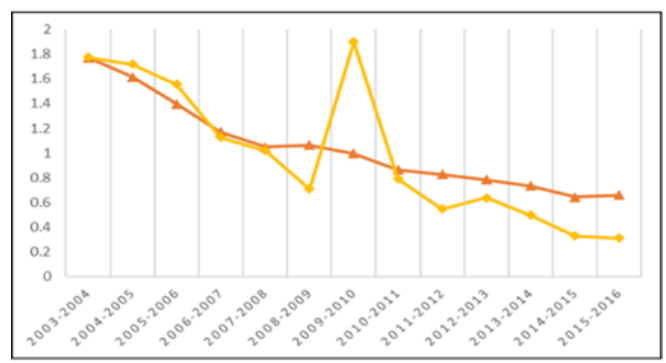

(c) $\mathrm{Dg}+\mathrm{Dp}$

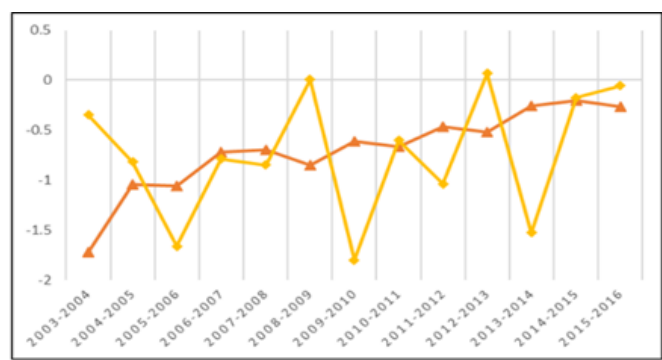

(b) $\mathrm{Dh}$

Figure 9. Comparison of the decoupling index of four factors between Beijing and Shanghai (a) is industrial structure decoupling index; (b) is industrial water utilization intensity decoupling index; (c) is the sum of economic development level decoupling index and the population size decoupling index.

The population size effect presented weak decoupling state in 2003-2016, and the decoupling index has also shown a downward trend year by year, reflecting that the two cities are also trying to control the water consumption while expanding the population size. In comparison between the two cities, the difference in the decoupling index is not obvious, and the trend of change is basically the same. Figure $9 \mathrm{c}$ presents the sum of economic development level decoupling index and the population size decoupling index. In recent years, Shanghai's decoupling state is better. It can be seen that although the economic development level effect and population size effect of the two megacities do not effectively drive the decoupling between industrial water use and economic growth, they also maintain their progress year by year.

\subsection{Discussion}

Through the above results, it is clear that the research in this paper is technically feasible. In addition, this section will further discuss the global significance of this article. In this paper, both theoretical and practical aspects have some implications in addition to technical results.

Regarding theoretical aspects, this paper provided a comprehensive method system. We drew a chart of modeling concepts and methodologies to demonstrate the modeling concepts clearly, the process is shown in Figure 10 [42]. Firstly, the decoupling model is constructed to calculate the decoupling index, and the decoupling state is divided according to the decoupling index to determine the level of decoupling. Secondly, in order to further explore the driving factors of decoupling, the extended kaya identities are constructed, giving each variable economic significance. Thirdly, using the LMDI decomposition method, the amount of water change during the study period is decomposed into the sum of the changes in the driving factors. The contribution of each factor to the overall change can be obtained. Finally, combined with decoupling and LMDI, the decoupling state of each driving factor was studied. We can explore the commonalities and differences between factors and study the deeper meaning. To further explain the concept of Figure 10, we have drawn a method flow chart and listed the relevant formulas, as shown in Figure 11 [50]. This method can be used to study the decoupling of urban water use and economic growth. A large number of papers indicate that the results of this analytical method are reliable. Whether it is large, medium or small cities, this research 
method has applicability. It can also be used for research in both developed and developing countries. Therefore, the theoretical aspect of this paper is of global significance.

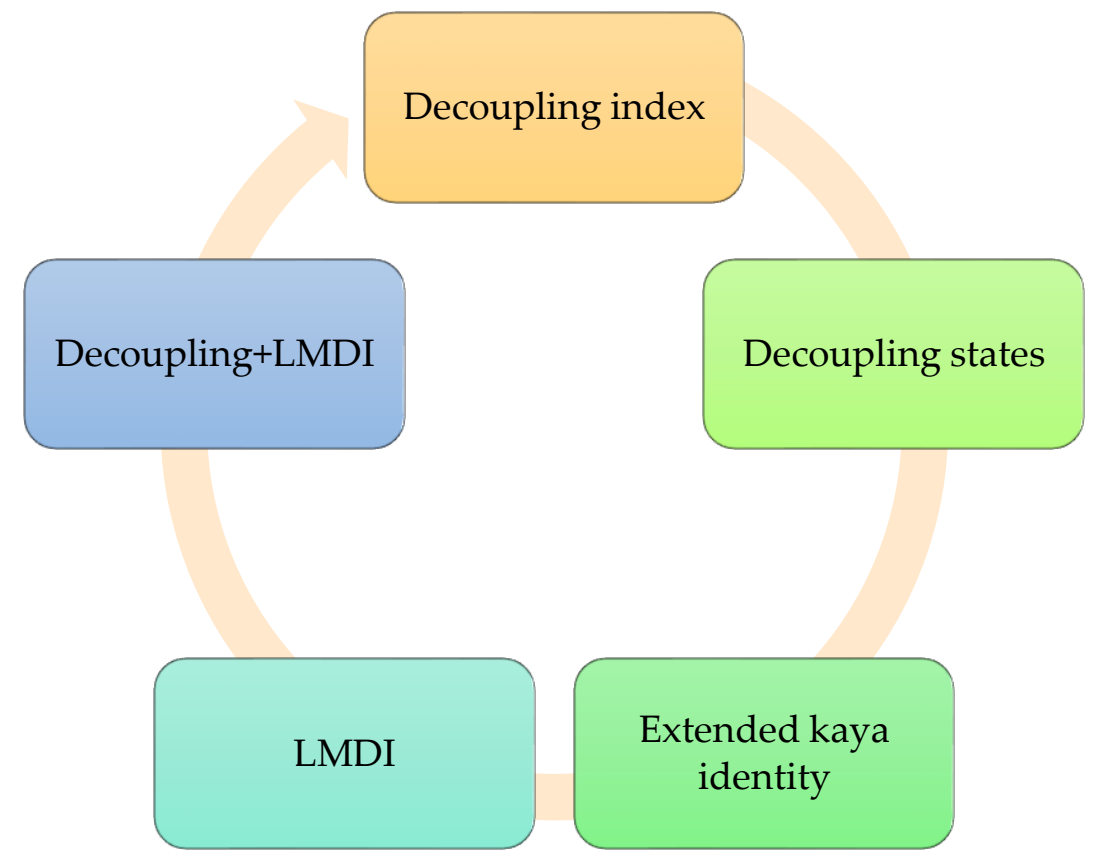

Figure 10. Modeling concepts and methodologies.

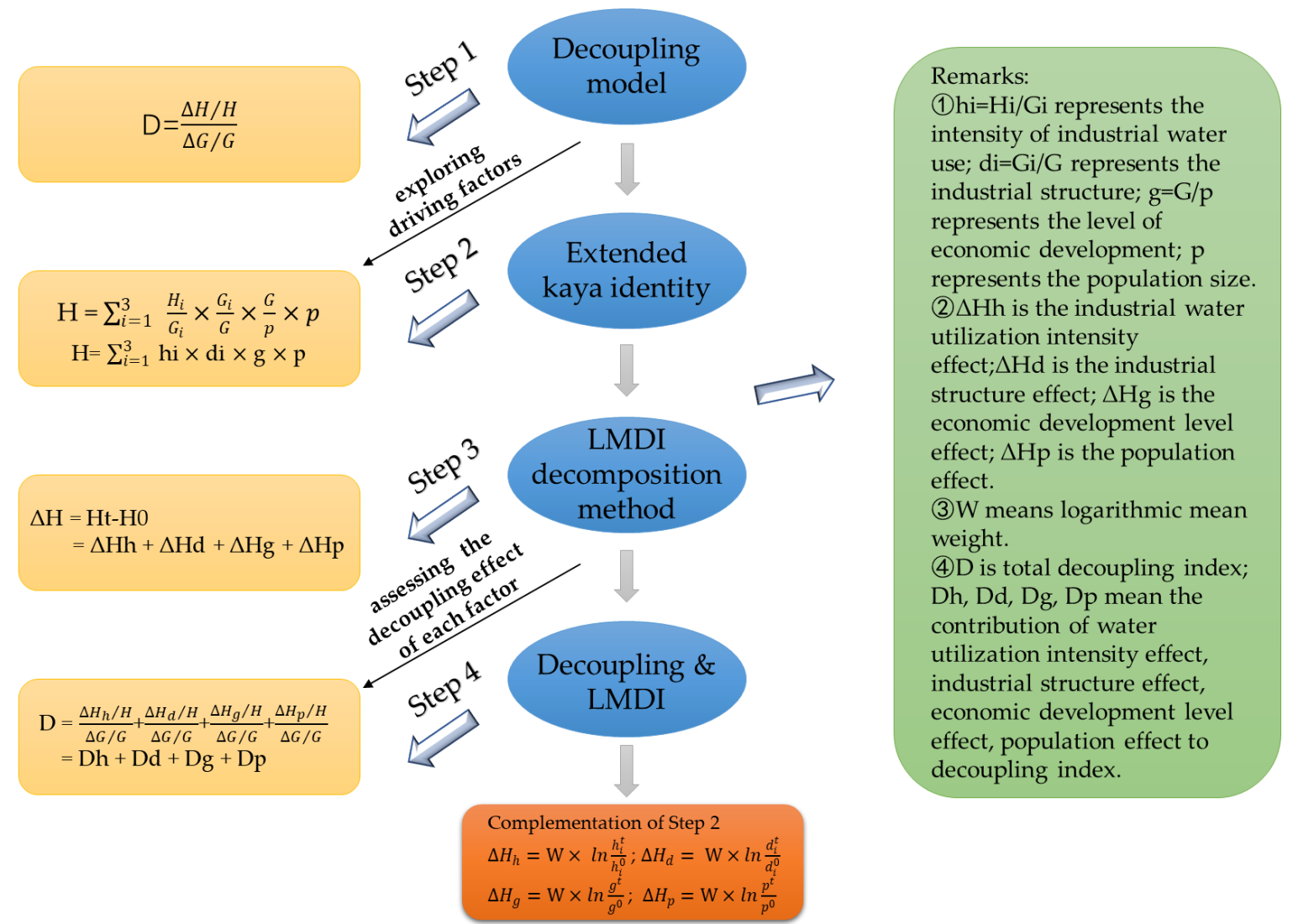

Figure 11. Flow chart of methodologies.

Regarding practical aspects, this paper has certain reference significance for developing countries. The top 20 of the world's megacities are shown in Table 5. We can see that most of these cities are 
located in developing countries, and Beijing and Shanghai are among them. Other cities in these cities have similar characteristics to Beijing and Shanghai. They showed rapid population expansion to drive urban economic development, and limited water resources led to a growing conflict between urban development and water resources. For example, India's Delhi has a population growth rate of $81.7 \%$ in 2000-2018 and is expected to reach 38.94 million in 2030. However, its water supply situation is not optimistic. Due to the large population, the city often suffers from a shortage of water, and the surface water pollution is very serious, and the exploitation of groundwater has already been overloaded [74]. Therefore, the decoupling of urban development from water is very important. The results of this paper and policy recommendations can provide some reference for these megacities. They can implement relevant policies by combining the city's own characteristics to improve water resources conflicts and promote economic development and decoupling of water use. Therefore, this study has important reference significance for the sustainable development of megacities in developing countries.

Table 5. The world's 20 Megacities.

\begin{tabular}{|c|c|c|c|c|c|}
\hline Ranking & Megacities & $\begin{array}{c}2018 \\
\text { Population }\end{array}$ & $\begin{array}{l}\text { 2000-2018 } \\
\text { Population } \\
\text { Growth }\end{array}$ & $\begin{array}{l}\text { Percent of } \\
\text { City's } \\
\text { Population }\end{array}$ & $\begin{array}{l}\text { Estimated } 2030 \\
\text { Population }\end{array}$ \\
\hline 1 & Tokyo, Japan & 37.5 million & $+8.8 \%$ & $29.5 \%$ & 36.57 million \\
\hline 2 & Delhi, India & 28.5 million & $+81.7 \%$ & $2.1 \%$ & 38.94 million \\
\hline 3 & Shanghai, China & 25.6 million & $+79.6 \%$ & $1.8 \%$ & 32.87 million \\
\hline 4 & São Paulo, Brazil & 21.7 million & $+27.2 \%$ & $10.3 \%$ & 23.82 million \\
\hline 5 & $\begin{array}{l}\text { Ciudad de México } \\
\text { (Mexico City), Mexico }\end{array}$ & 21.6 million & $+16.9 \%$ & $16.5 \%$ & 24.11 million \\
\hline 6 & $\begin{array}{c}\text { Al-Qahirah (Cairo), } \\
\text { Egypt }\end{array}$ & 20.1 million & $+47.3 \%$ & $20.2 \%$ & 25.52 million \\
\hline 7 & Mumbai, India & 20.0 million & $+23.7 \%$ & $1.5 \%$ & 24.57 million \\
\hline 8 & Beijing, China & 19.6 million & $+90.7 \%$ & $1.4 \%$ & 24.28 million \\
\hline 9 & Dhaka, Bangladesh & 19.6 million & $+90.4 \%$ & $11.8 \%$ & 28.08 million \\
\hline 10 & $\begin{array}{l}\text { Kinki M.M.A. (Osaka), } \\
\text { Japan }\end{array}$ & 19.3 million & $+3.3 \%$ & $15.2 \%$ & 18.66 million \\
\hline 11 & $\begin{array}{c}\text { New York-Newark, } \\
\text { America }\end{array}$ & 18.8 million & $+5.6 \%$ & $5.8 \%$ & 19.96 million \\
\hline 12 & Karachi, Pakistan & 15.4 million & $+56.7 \%$ & $7.7 \%$ & 20.43 million \\
\hline 13 & $\begin{array}{c}\text { Buenos Aires, } \\
\text { Argentina }\end{array}$ & 15.0 million & $+19.7 \%$ & $33.5 \%$ & 16.46 million \\
\hline 14 & Chongqing, China & 14.8 million & $+88.7 \%$ & $1.0 \%$ & 19.65 million \\
\hline 15 & Istanbul, Turkey & 14.8 million & $+68.7 \%$ & $18.0 \%$ & 17.12 million \\
\hline 16 & $\begin{array}{c}\text { Kolkata (Calcutta), } \\
\text { India }\end{array}$ & 14.7 million & $+12.1 \%$ & $1.1 \%$ & 17.58 million \\
\hline 17 & Manila, Philippines & 13.5 million & $+35.4 \%$ & $12.7 \%$ & 16.84 million \\
\hline 18 & Lagos, Nigeria & 13.5 million & $+84.9 \%$ & $6.9 \%$ & 20.60 million \\
\hline 19 & Rio de Janeiro, Brazil & 13.3 million & $+17.6 \%$ & $6.3 \%$ & 14.41 million \\
\hline 20 & Tianjin, China & 13.2 million & $+89.1 \%$ & $0.9 \%$ & 15.75 million \\
\hline
\end{tabular}

\subsection{Future Research}

There are few gaps in this paper need to be covered in the future. Regarding the limitation of research method, we believe that any research method has a scope of application. The research method in this paper can only reflect the macro level, which cannot be reflected at the micro level, such as individual behavior. China is currently in the process of industrialization, and the government dominates the economy. Obviously, the government's macro-control has a great effect, so this method is suitable for the study of this paper. In the future, when China begins its post-industrialization process, new models are needed for further research. 


\section{Conclusions and Recommendations}

\subsection{Conclusions}

This paper study the decoupling relationship between urban water use and economic growth by Tapio decoupling theory, and further apply LMDI method to decompose the driving factors, and then focus on a comparative study of two megacities-Beijing and Shanghai. Key conclusions were as follows.

(1) The decoupling states of water use and economic growth in Beijing and Shanghai in 2003-2016 were dominated by strong decoupling and weak decoupling, and the decoupling levels of both cities were well. Shanghai's strong decoupling status is more frequent than in Beijing, and Shanghai's decoupling efforts are relatively better than Beijing.

(2) The decoupling state of the three industries in Beijing was relatively stable during the study period. Beijing's primary industry and secondary industry mainly showed a strong decoupling state, and the decoupling effect was well, while the tertiary industry experienced expansive negative decoupling level in recent years. Shanghai's primary industry and secondary industry presented negative decoupling and weak decoupling during the study period, while the tertiary industry presented the opposite, mainly showing weak decoupling and strong decoupling. The decoupling efforts of Beijing's primary and secondary industries are better than those of Shanghai, while the tertiary industry is the opposite.

(3) The common characteristics that drive the two megacities' decoupling are industrial structure effect and industrial water utilization intensity effect. And both effects show a strong decoupling state. The industrial structure of the two cities is optimized year by year, and the intensity of industrial water use is decreasing year by year. Regarding industrial structure effect, the decoupling index of Beijing's industrial structure is lower than that of Shanghai, and the effect of Beijing's industrial structure on decoupling is better than that of Shanghai. Regarding industrial water utilization intensity effect, Shanghai's water utilization intensity has been declining year by year faster than Beijing, and Shanghai's decoupling index is lower. Shanghai's water efficiency is improving faster.

(4) The economic development level effect and population size effect of the two megacities mainly presented weak decoupling. Although they do not effectively drive the decoupling between urban water use and economic growth in Beijing and Shanghai, the decoupling index shows a downward trend year by year, and the decoupling state is gradually optimized.

(5) The reason why Shanghai's decoupling effect is better than Beijing is that Shanghai's industrial water utilization intensity factor promotes decoupling more effectively, and the factors of economic development level effect and population size effect that inhibit decoupling are weaker. Although the industrial structure effect drives the decoupling is not as good as Beijing, Shanghai's decoupling effect is better in general.

\subsection{Recommendations}

According to the research results, in order to promote the decoupling of water consumption and economic growth in China's cities and promote the sustainable development of urban water use, the following suggestions are proposed.

- Actively look for new ways to optimize the industrial structure and promote the transformation and upgrading of industrial structure, shifting the focus of production to the tertiary industry with low water consumption and high production capacity. The government should encourage and promote the development of the tertiary industry on the basis of maintaining the healthy development of the primary and secondary industries. Reduce agricultural water use and achieve zero or even negative growth in agricultural water use. Formulate relevant policies, optimize resource allocation, and guide the adjustment of industrial structure. Enterprises should strengthen the use of emerging technologies such as artificial intelligence, big data, and Internet 
of Things to accelerate the development of smart manufacturing, promote the high-quality development of manufacturing, and realize the transformation of industrial economy into a service-oriented economy. At the same time, the rise of the tertiary industry will also drive the progress of the primary and secondary industries. The three industries operate well, promoting the decoupling between water consumption and economic growth.

$>$ Further explore scientific water-saving technologies, improve water use efficiency, reduce water utilization intensity, and reduce water consumption per unit of GDP. Use innovative new methods to reduce water utilization intensity and use less water to create more value. For example, learning advanced water-saving irrigation technology from other countries, reducing the water consumption per unit of cultivated land. At the same time, the government should provide corresponding financial support, policy support, etc., and establish and continuously improve the water-saving irrigation system. Actively promote high-end water-saving production technology and equipment to directly reduce water consumption and increase production efficiency. Encourage the development of talents, promote the exchange of innovative elements such as talents, capital, technology, and information in the service industry, and gradually fill the shortcomings in the development of the service industry. Strengthen exchanges and cooperation with pollution control and water-saving technologies in various regions, so that advanced technologies can be rapidly promoted and applied.

$>$ Develop and implement a strict water management system. Combined with the data of urban water use and economic development in previous years, the government should propose corresponding water-saving indicators for each city and industry. For example, set strict water standards and establish stepped water prices. Real-time observation of industrial structure, water utilization intensity, economic development level, population size to contribute to water conservation, timely adjustment of corresponding indicators.

$>$ Establish the concept of citizen water conservation. With the expansion of the population, everyone has a role to play in water consumption. If the awareness of water conservation is deeply rooted in the hearts of the people, everyone will start from small things around them, which will play a pivotal role in building a water-saving society and promoting the sustainable development of water resources.

\subsection{Implication}

From the perspective of theory and practice, this paper has some implications except technical results. Regarding theoretical aspects, the research method of this paper is the comprehensive analysis of decoupling and LMDI. The method system is clear and applicable to both developing and developed countries. It is of global significance. Regarding practical aspects, this paper has certain reference significance for developing countries. The world's megacities are mainly distributed in developing countries and are also facing water conflicts. The results of this paper provide them with reference to facilitate the adoption of relevant policies and measures to maintain sustainable development.

Author Contributions: R.L. conceived and designed the experiments, wrote the original paper; X.W. performed the experiments, and analyzed the data; R.L. contributed analysis tools and revised the original paper. All authors read and approved the final manuscript.

Funding: This research was funded by Humanities and Social Science Fund of Ministry of Education of China (Grant No.18YJA790081), and Natural Science Foundation of Shandong Province, China (Grant No. ZR2018MG016).

Conflicts of Interest: The authors declare no conflict of interest. 


\section{References}

1. Tiziano, D.; Scott, K. Are we in deep water? Water scarcity and its limits to economic growth. Ecol. Econ. 2017, 142, 130-147.

2. Cecilia, S.; Sam, E.; Jiang, L.; David, R.-H. Low carbon growth in China: The role of emissions trading in a transitioning economy. Appl. Energy 2019, 235, 1118-1125.

3. Udimal, T.B.; Zhuang, J.; Ayamba, E.C.; Owusu, S.M. China's water situation; the supply of water and the pattern of its usage. Int. J. Sustain. Built Environ. 2017, 6, 491-500. [CrossRef]

4. Ma, W.; Wang, Q.; Yang, H.; Zhang, A.; Zhang, Y. Effects of Beijing-Shanghai high-speed rail on air travel: Passenger types, airline groups and tacit collusion. Rese. Transp. Econ. 2019, 74, 64-76. [CrossRef]

5. Wenpeng, L.I. Emergency Plan for Water Supply in Consecutive Droughts and Sustainable Water Resources Management in Beijing. Acta Geol. Sin. 2018, 92, 1231-1244.

6. Asim, N.; Marco, C. Exploring urban energy-water nexus embodied in domestic and international trade: A case of Shanghai. J. Clean. Prod. 2019, 223, 522-535.

7. Cheng, J. Implement the most stringent water resources management system to achieve coordinated development of water and economic society. In Proceedings of the China Water Resources Magazine Expert Committee Meeting and Accelerating Water Conservancy Reform and Development High-Level Seminar, Beijing Water Resources Bureau, Beijing, China, 18 March 2011.

8. Zhang, N. Close integration of law enforcement and law enforcement, seamless integration of legislation and law enforcement-Municipal People's Congress Standing Committee conducts air pollution control and water resources management law enforcement inspection. Shanghai People's Congr. Mon. 2018, 339, 23.

9. Cui, X.; Wei, X.; Liu, W.; Zhang, F.; Li, Z. Spatial and temporal analysis of carbon sources and sinks through land use/cover changes in the Beijing-Tianjin-Hebei urban agglomeration region. Phys. Chem. Earth 2019, 110, 61-70. [CrossRef]

10. Sun, Y.; Gao, C.; Li, J.; Wang, R.; Liu, J. Evaluating urban heat island intensity and its associated determinants of towns and cities continuum in the Yangtze River Delta urban agglomerations. Sustain. Cities Soc. 2019. [CrossRef]

11. Oecd. Indicators to Measure Decoupling of Environmental Pressure from Economic Growth. 2002. Available online: http://www.olis.oecd.org/olis/2002doc.nsf/LinkTo/sg-sd2002 (accessed on 28 June 2019).

12. Juknys, R. Transition Period in Lithuania-Do We Move to Sustainability? Energy 2003, 4, 4-9.

13. Vehmas, J.; Kaivo-oja, J.; Luukkanen, J. Global Trends of Linking Environmental Stress and Economic Growth; Finland Futures Research Centre: Turku, Finland, 2003; Volume 6.

14. Tapio, P. Towards a theory of decoupling: Degrees of decoupling in the EU and the case of road traffic in Finland between 1970 and 2001. Transp. Policy 2005, 12, 137-151. [CrossRef]

15. Zhong, T.; Huang, X.; Han, L.; Wang, B. Research progress on decoupling analysis of resources and environment. J. Nat. Resour. 2010, 8, 1400-1412.

16. Song, W. Decoupling cultivated land loss by construction occupation from economic growth in Beijing. Habitat Int. 2014, 43, 198-205. [CrossRef]

17. Gokarakonda, S.; Shrestha, S.; Caleb, P.R.; Rathi, V.; Jain, R.; Thomas, S.; Topp, K.; Niazi, Z. Decoupling in India's building construction sector: Trends, technologies and policies. Build. Res. Inf. 2019, 47, 91-107. [CrossRef]

18. Fan, F.; Lei, Y. Responsive relationship between energy-related carbon dioxide emissions from the transportation sector and economic growth in Beijing-Based on decoupling theory. Int. J. Sustain. Transp. 2017, 11, 764-775. [CrossRef]

19. Wang, Y.; Xie, T.; Yang, S. Carbon emission and its decoupling research of transportation in Jiangsu Province. J. Clean. Prod. 2017, 142, 907-914. [CrossRef]

20. Jiang, J.-J.; Ye, B.; Zhou, N.; Zhang, X.-L. Decoupling analysis and environmental Kuznets curve modelling of provincial-level $\mathrm{CO}_{2}$ emissions and economic growth in China: A case study. J. Clean. Prod. 2019, 212, 1242-1255. [CrossRef]

21. Chen, B.; Yang, Q.; Li, J.; Chen, G. Decoupling analysis on energy consumption, embodied GHG emissions and economic growth-The case study of Macao. Renew. Sustain. Energy Rev. 2017, 67, 662-672. [CrossRef]

22. Zhang, Y.; Nie, R.; Shi, R.; Zhang, M. Measuring the capacity utilization of the coal sector and its decoupling with economic growth in China's supply-side reform. Resour. Conserv. Recycl. 2018, 129, 314-325. [CrossRef] 
23. Cui, C.X.; Hanley, N.; McGregor, P.; Swales, K.; Turner, K.; Yin, Y.P. Impacts of regional productivity growth, decoupling and pollution leakage. Reg. Stud. 2017, 51, 1324-1335. [CrossRef]

24. Yuan, Y.; Wu, S.; Yu, Y.; Tong, G.; Mo, L.; Yan, D.; Li, F. Spatiotemporal interaction between ecosystem services and urbanization: Case study of Nanjing City, China. Ecol. Indic. 2018, 95, 917-929. [CrossRef]

25. Shi, L.; Vause, J.; Li, Q.; Tang, L.; Zhao, J. Decoupling analysis of energy consumption and economic development in China. Energy Sources Part B Econ. Plan. Policy 2016, 11, 788-792. [CrossRef]

26. Wang, W.; Li, M.; Zhang, M. Study on the changes of the decoupling indicator between energy-related $\mathrm{CO}_{2}$ emission and GDP in China. Energy 2017, 128, 11-18. [CrossRef]

27. Dasgupta, S.; Roy, J. Analysing energy intensity trends and decoupling of growth from energy use in Indian manufacturing industries during 1973-1974 to 2011-2012. Energy Effic. 2017, 10, 925-943. [CrossRef]

28. Lesin, Y.V.; Fedulova, E.; Akulov, A.; Vik, S.; Korchagin, R. Water Resources Management In Support Of Raw Region Based On Decoupling Effect. In Proceedings of the IOP Conference Series: Earth and Environmental Science, Semarang, Indonesia, 16-18 January 2017; p. 012026.

29. Mikayilov, J.I.; Hasanov, F.J.; Galeotti, M. Decoupling of $\mathrm{CO}_{2}$ emissions and GDP: A time-varying cointegration approach. Ecol. Indic. 2018, 95, 615-628. [CrossRef]

30. Moreau, V.; Neves, C.A.D.O.; Vuille, F. Is decoupling a red herring? The role of structural effects and energy policies in Europe. Energy Policy 2019, 128, 243-252. [CrossRef]

31. Moutinho, V.; Fuinhas, J.A.; Marques, A.C.; Santiago, R. Assessing eco-efficiency through the DEA analysis and decoupling index in the Latin America countries. J. Clean. Prod. 2018, 205, 512-524. [CrossRef]

32. WARMING, M. Decoupling water from energy use must be a global priority. Water Wastewater Treat. WWT Irel. 2017, 60, 7 .

33. Csereklyei, Z.; Stern, D.I. Global energy use: Decoupling or convergence? Energy Econ. 2015, 51, 633-641. [CrossRef]

34. Tu, C.-J.; Chang, M.-C.; Chen, C.-P. Progressive time-weighted dynamic energy efficiency, energy decoupling rate, and decarbonization: An empirical study on G7 and BRICS. Sustainability 2016, 8, 928. [CrossRef]

35. Schandl, H.; Hatfield-Dodds, S.; Wiedmann, T.; Geschke, A.; Cai, Y.; West, J.; Newth, D.; Baynes, T.; Lenzen, M.; Owen, A. Decoupling global environmental pressure and economic growth: Scenarios for energy use, materials use and carbon emissions. J. Clean. Prod. 2016, 132, 45-56. [CrossRef]

36. Li, Y.-N.; Cai, M.; Wu, K.; Wei, J. Decoupling analysis of carbon emission from construction land in Shanghai. J. Clean. Prod. 2019, 210, 25-34. [CrossRef]

37. Xie, P.; Gao, S.; Sun, F. An analysis of the decoupling relationship between $\mathrm{CO}_{2}$ emission in power industry and GDP in China based on LMDI method. J. Clean. Prod. 2019, 211, 598-606. [CrossRef]

38. Ren, S.; Yin, H.; Chen, X.H. Using LMDI to analyze the decoupling of carbon dioxide emissions by China's manufacturing industry. J. Cent. South Univ. 2014, 9, 61-75. [CrossRef]

39. Boqiang, L.; Liu, K. Using LMDI to Analyze the Decoupling of Carbon Dioxide Emissions from China's Heavy Industry. Sustainability 2017, 9, 1198. [CrossRef]

40. Xu, S.-C.; Zhang, W.-W.; He, Z.-X.; Han, H.-m.; Long, R.-Y.; Chen, H. Decomposition analysis of the decoupling indicator of carbon emissions due to fossil energy consumption from economic growth in China. Energy Effic. 2017, 10, 1365-1380. [CrossRef]

41. Zhao, R.; Liu, Y.; Tian, M.; Ding, M.; Cao, L.; Zhang, Z.; Chuai, X.; Xiao, L.; Yao, L. Impacts of water and land resources exploitation on agricultural carbon emissions: The water-land-energy-carbon nexus. Land Use Policy 2018, 72, 480-492. [CrossRef]

42. Wang, Z.-X.; Ye, D.-J. Forecasting Chinese carbon emissions from fossil energy consumption using non-linear grey multivariable models. J. Clean. Prod. 2017, 142, 600-612. [CrossRef]

43. Dong, J.-F.; Deng, C.; Wang, X.-M.; Zhang, X.-L. Multilevel index decomposition of energy-related carbon emissions and their decoupling from economic growth in Northwest China. Energies 2016, 9, 680. [CrossRef]

44. Zhao, X.; Zhang, X.; Li, N.; Shao, S.; Geng, Y. Decoupling economic growth from carbon dioxide emissions in China: A sectoral factor decomposition analysis. J. Clean. Prod. 2017, 142, 3500-3516. [CrossRef]

45. Jiang, X.-T.; Dong, J.-F.; Wang, X.-M.; Li, R.-R. The multilevel index decomposition of energy-related carbon emission and its decoupling with economic growth in USA. Sustainability 2016, 8, 857. [CrossRef]

46. Dong, B.; Zhang, M.; Mu, H. Study on decoupling analysis between energy consumption and economic growth in Liaoning Province. Energy Policy 2016, 97, 414-420. [CrossRef] 
47. Wang, Q.; Jiang, R. Is China's economic growth decoupled from carbon emissions? J. Clean. Prod. 2019, 225, 1194-1208. [CrossRef]

48. Wang, Q.; Jiang, R.; Zhan, L. Is decoupling economic growth from fuel consumption possible in developing countries?-A comparison of China and India. J. Clean. Prod. 2019, 229, 806-817. [CrossRef]

49. Zhou, X.; Zhang, M.; Zhou, M.; Zhou, M. A comparative study on decoupling relationship and influence factors between China's regional economic development and industrial energy-related carbon emissions. J. Clean. Prod. 2017, 142, 783-800. [CrossRef]

50. Wang, Q.; Wang, S. A comparison of decomposition the decoupling carbon emissions from economic growth in transport sector of selected provinces in eastern, central and western China. J. Clean. Prod. 2019, 229, 570-581. [CrossRef]

51. Wang, Q.; Zhao, M.; Li, R. Decoupling sectoral economic output from carbon emissions on city level: A comparative study of Beijing and Shanghai, China. J. Clean. Prod. 2019, 209, 126-133. [CrossRef]

52. Roinioti, A.; Koroneos, $\mathrm{C}$. The decomposition of $\mathrm{CO}_{2}$ emissions from energy use in Greece before and during the economic crisis and their decoupling from economic growth. Renew. Sustain. Energy Rev. 2017, 76, 448-459. [CrossRef]

53. Leal, P.A.; Marques, A.C.; Fuinhas, J.A. Decoupling economic growth from GHG emissions: Decomposition analysis by sectoral factors for Australia. Econ. Anal. Policy 2019, 62, 12-26. [CrossRef]

54. Song, Y.; Zhang, M. Using a new decoupling indicator (ZM decoupling indicator) to study the relationship between the economic growth and energy consumption in China. Nat. Hazards 2017, 88, 1013-1022. [CrossRef]

55. Ning, Y.; Zhang, B.; Ding, T.; Zhang, M. Analysis of regional decoupling relationship between energy-related CO 2 emission and economic growth in China. Nat. Hazards 2017, 87, 867-883. [CrossRef]

56. Wang, Q.; Su, M.; Li, R. Toward to economic growth without emission growth: The role of urbanization and industrialization in China and India. J. Clean. Prod. 2018, 205, 499-511. [CrossRef]

57. Wang, Q.; Zhao, M.; Li, R.; Su, M. Decomposition and decoupling analysis of carbon emissions from economic growth: A comparative study of China and the United States. J. Clean. Prod. 2018, 197, 178-184. [CrossRef]

58. Wang, Q.; Wang, S. Decoupling Economic Growth from Carbon Emissions Growth in the United States: The Role of Research and Development. J. Clean. Prod. 2019. [CrossRef]

59. Ang, B.W.; Choi, K.-H. Decomposition of aggregate energy and gas emission intensities for industry: A refined Divisia index method. Energy J. 1997, 18, 59-73. [CrossRef]

60. Sun, J.; Ang, B. Some properties of an exact energy decomposition model. Energy 2000, 25, 1177-1188. [CrossRef]

61. Liu, B.W.; Zhang, X.; Yang, L. Research on Decoupling of Regional Industrial Carbon Emission Based on LMDI. China's Popul. Resour. Environ. 2018, 28, 78-86.

62. Hu, M.; Hu, Y.; Yuan, J.; Lu, F. Decomposing the decoupling of water consumption and economic growth in Jiangxi, China. J. Water Reuse Desalin. 2019, 9, 94-104. [CrossRef]

63. Wang, S.; Li, R. Toward the coordinated sustainable development of urban water resource use and economic growth: An empirical analysis of Tianjin City, China. Sustainability 2018, 10, 1323. [CrossRef]

64. Qiu, L.; Huang, J.; Niu, W. Decoupling and Driving Factors of Economic Growth and Groundwater Consumption in the Coastal Areas of the Yellow Sea and the Bohai Sea. Sustainability 2018, 10, 4158. [CrossRef]

65. Li, Y.; Luo, Y.; Wang, Y.; Wang, L.; Shen, M. Decomposing the decoupling of water consumption and economic growth in china's textile industry. Sustainability 2017, 9, 412. [CrossRef]

66. Zhang, C.; Zhong, L.; Wang, J. Decoupling between water use and thermoelectric power generation growth in China. Nat. Energy 2018, 3, 792-799. [CrossRef]

67. Li, Y.; Fang, D.; Wang, S.; Chen, B. Driving Forces Analysis of Water Consumption in the Energy Production Process in China Based on the LMDI Method. DEStech Trans. Environ. Energy Earth Sci. 2018. [CrossRef]

68. Zhang, S.; Su, X.; Singh, V.P.; Ayantobo, O.O.; Xie, J. Logarithmic Mean Divisia Index (LMDI) decomposition analysis of changes in agricultural water use: A case study of the middle reaches of the Heihe River basin, China. Agric. Water Manag. 2018, 208, 422-430. [CrossRef]

69. Kaya, Y. Impact of Carbon Dioxide Emission Control on GNP Growth: Interpretation of Proposed Scenarios; IPCC Energy and Industry Subgroup, Response Strategies Working Group: Paris, France, 1989.

70. McNicoll, G.; IPAT (Impact, Population, Affluence, and Technology). International Encyclopedia of the Social E Behavioral Sciences, 2nd ed.; Elsevier: Amsterdam, The Netherlands, 2015; pp. 716-718. Available online: http://www.sciencedirect.com/science/article/pii/B9780080970868910456 (accessed on 28 June 2019). 
71. National Bureau of Statistics. China Statistical Yearbook; China Statistics Press: Beijing, China, 2004-2017.

72. Beijing Municipal Bureau of Statistics. Beijing Statistical Yearbook; China Statistics Press: Beijing, China, 2004-2017.

73. Shanghai Municipal Bureau of Statistics. Shanghai Statistical Yearbook; China Statistics Press: Shanghai, China, 2004-2017.

74. Acharya, S.; Sharma, S.K.; Khandega, V. Assessment of groundwater quality by water quality indices for irrigation and drinking in South West Delhi, India. Data Brief 2018, 18, 2019-2028. [CrossRef]

(C) 2019 by the authors. Licensee MDPI, Basel, Switzerland. This article is an open access article distributed under the terms and conditions of the Creative Commons Attribution (CC BY) license (http://creativecommons.org/licenses/by/4.0/). 